\title{
مستقبل الصناعة العربية في ظل اقتصاد عالمي متغير
}

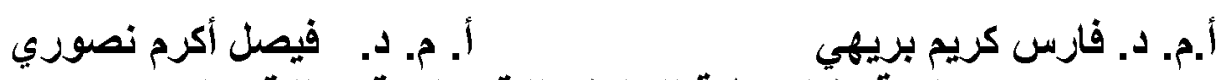 \\ جامعة بذاد- كلية الادارة والاقتصاد- قسم الاقتصاد
}

المقدهة

أن التطور الاقتصادي في أيسة دولة إنما يقاس بالدور الذي بلئه القطاع الصناعي في اقتصادياتها،

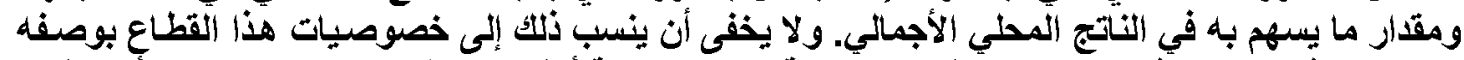

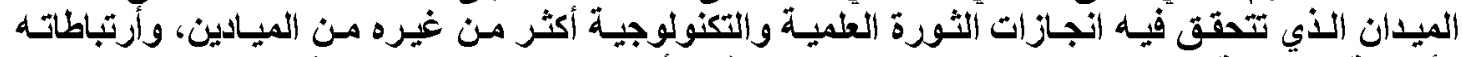

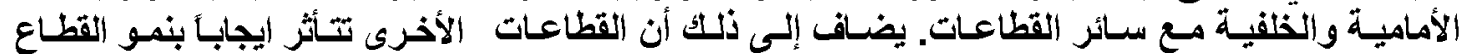

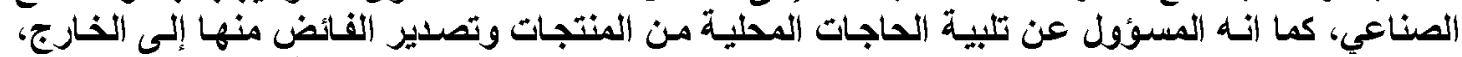

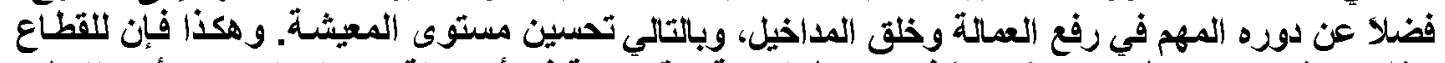

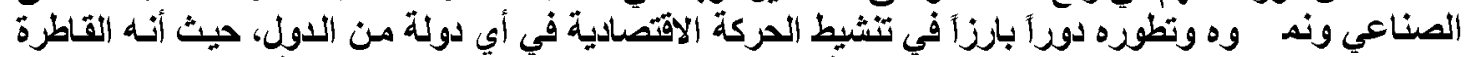

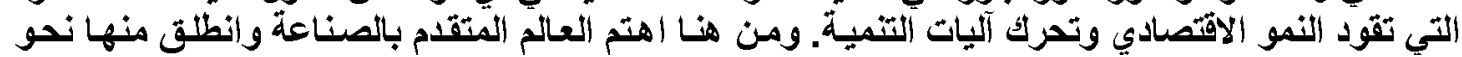

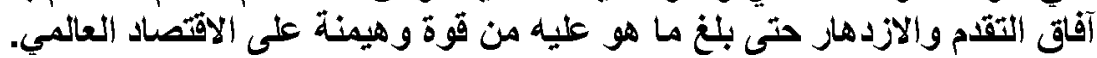

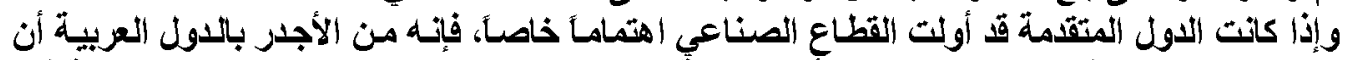

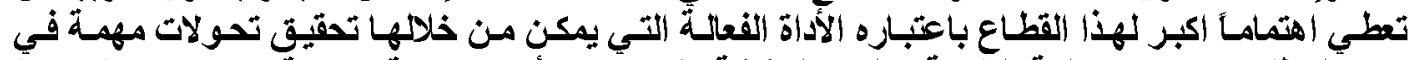

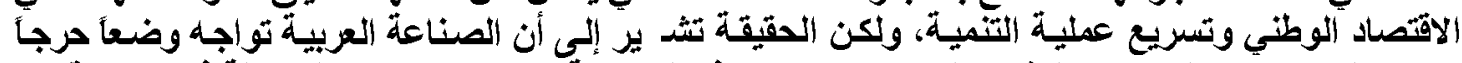

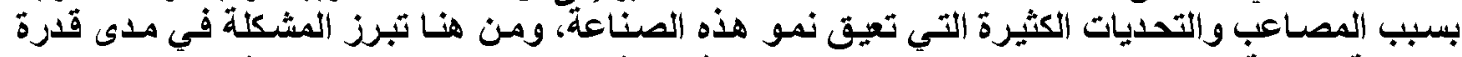

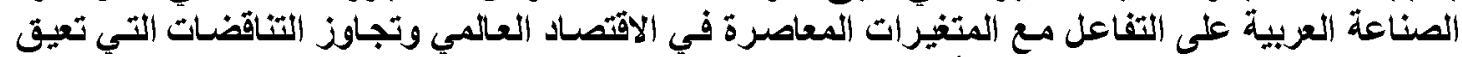

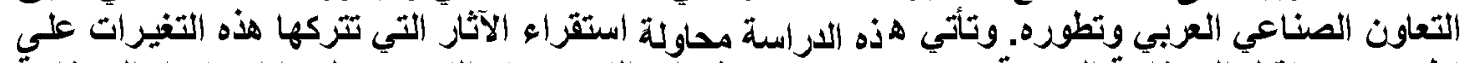

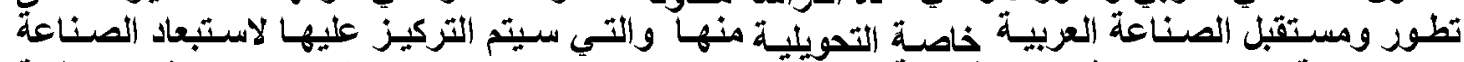

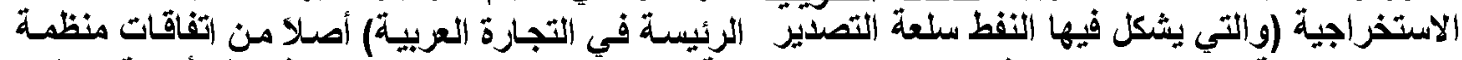

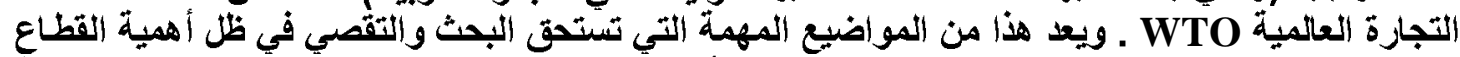

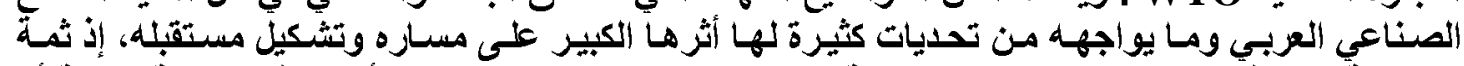

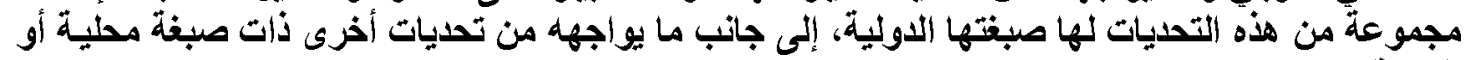

إقليمية.

\section{فرضية البحث}

تفرض التغيرات والتطورات العالمية اعادة النظر في السياسيات الأقتصادية المتبعة في الدول العريية،

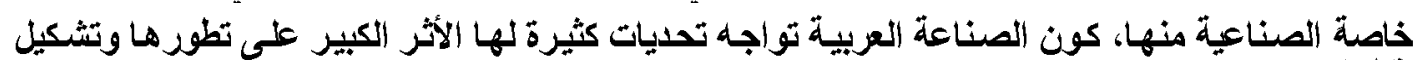

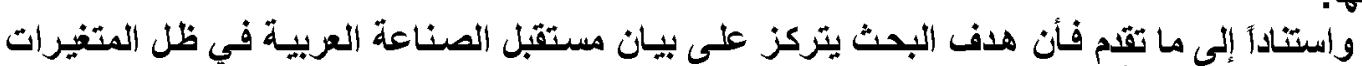

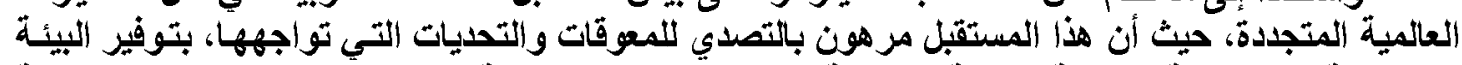

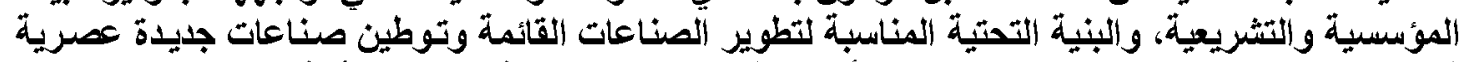

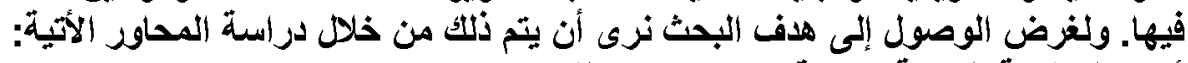
أولا: الصناعة العربية ... واقعها واتجاهات النهات النمو.

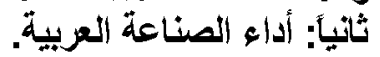

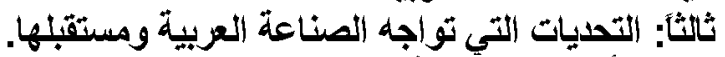

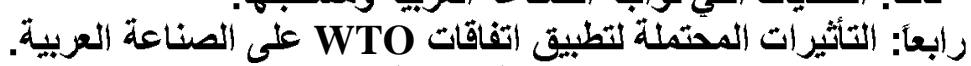
خامسا: استثراف مستقبل الصناعة العربية. 
أولا- الصناعة العربية... واقعها واتجاهات النمو

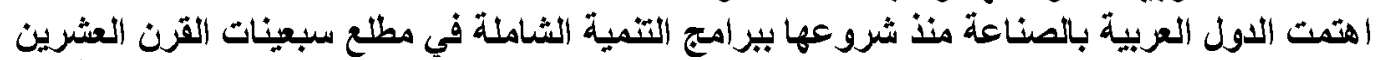

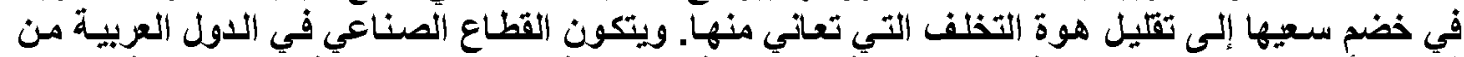

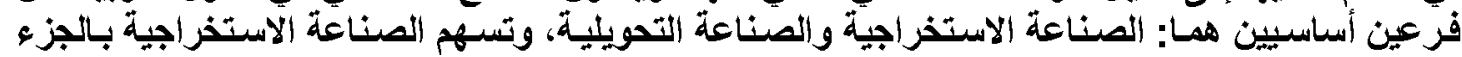

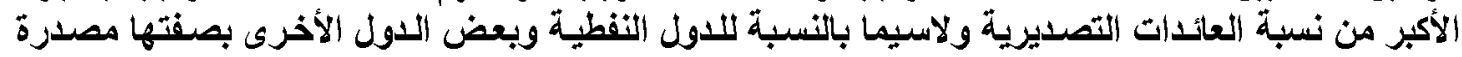

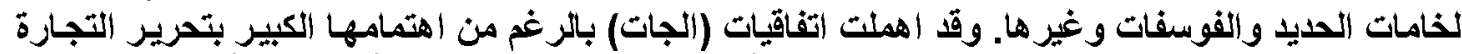

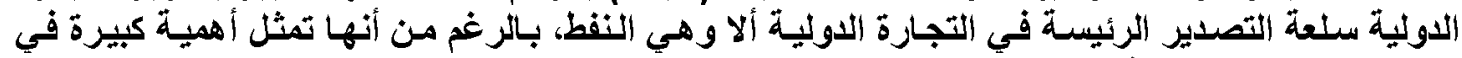

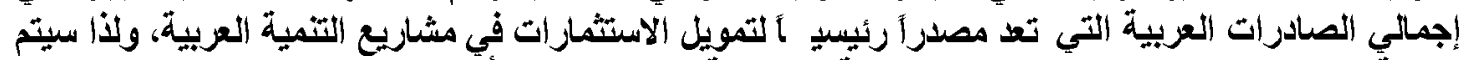

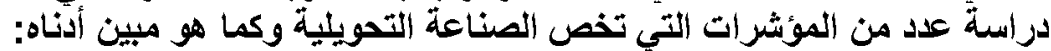

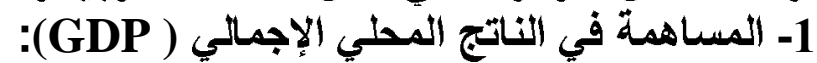

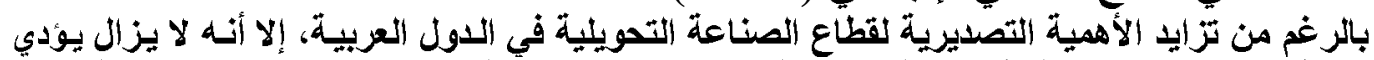

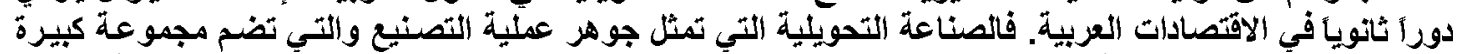

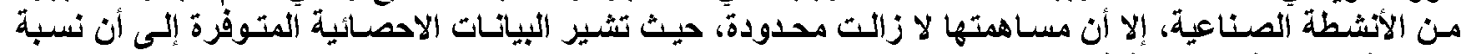

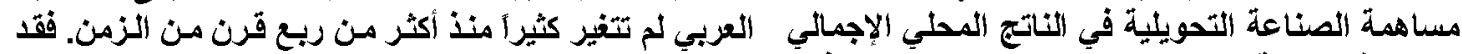

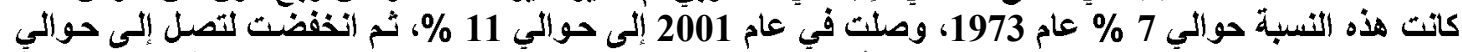

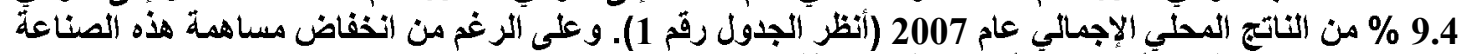

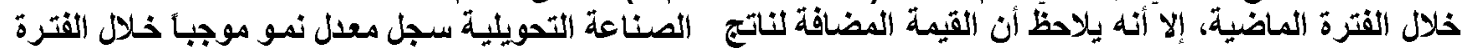

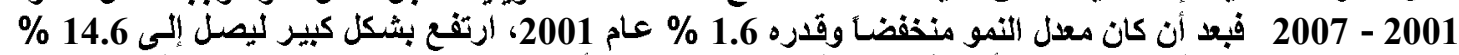

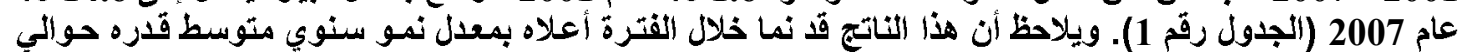

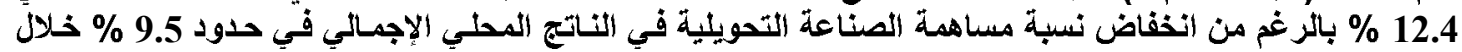

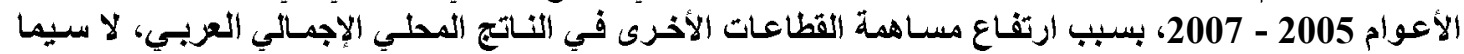
مساهمة الصناعة الاستخراجية التي ارتفعت من حوالي 27.2 \% عام 2001 إلى حوالى 40 \% عام 2007.

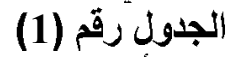

تطور الناتج الصناعي العربي بالأسعار الجارية للفترة 2000 - 2007

(مليار دولار)

\begin{tabular}{|c|c|c|c|c|c|c|c|c|c|}
\hline \multicolumn{3}{|c|}{ إجمائي القطاع الصناعى } & \multicolumn{3}{|c|}{ الصناعة التحويلية } & \multicolumn{3}{|c|}{ الصناعة الاستخراجية } & \multirow[b]{2}{*}{ السنة } \\
\hline فالّي الناتج & $\begin{array}{c}\text { معلن النسنوي } \\
\text { \% }\end{array}$ & المضيفة & 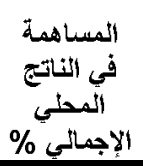 & السنوي \% معل النمو & المضيفة & 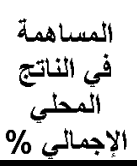 & معلز الأنمو & المضيفة & \\
\hline 41.6 & 40.9 & 281.7 & 10.6 & 5.7 & 71.9 & 31.0 & 59.0 & 209.8 & 2000 \\
\hline 38.0 & 9.9 - & 253.9 & 11.0 & 1.7 & 73.0 & 27.2 & $13.8-$ & 180.9 & 2001 \\
\hline 38.1 & 1.1 & 256.6 & 11.1 & 2.4 & 74.7 & 27.0 & 0.5 & 181.8 & 2002 \\
\hline 39.9 & 17.6 & 301.7 & 10.9 & 10.5 & 82.6 & 29.0 & 20.5 & 219.1 & 2003 \\
\hline 43.3 & 28.0 & 386.1 & 10.5 & 13.7 & 93.9 & 32.8 & 33.4 & 292.2 & 2004 \\
\hline 48.4 & 36.6 & 527.3 & 9.8 & 13.5 & 106.6 & 38.6 & 44.0 & 420.7 & 2005 \\
\hline 49.8 & 22.0 & 643.3 & 9.4 & 13.4 & 120.9 & 40.5 & 24.2 & 522.4 & 2006 \\
\hline 49.2 & 12.5 & 724.0 & 9.4 & 14.6 & 138.6 & 39.8 & 12.1 & 585.4 & 2007 \\
\hline
\end{tabular}

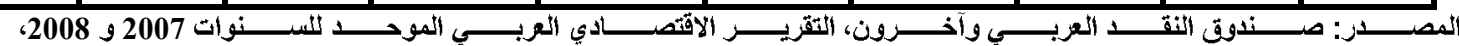

( 66 ) 


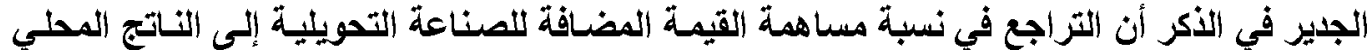

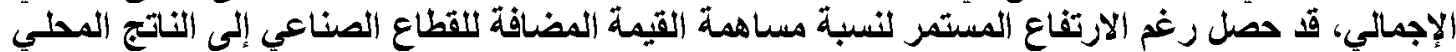

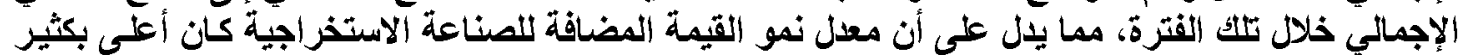

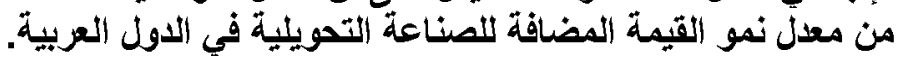

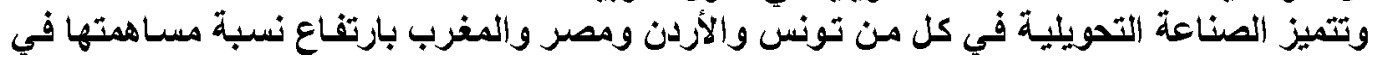

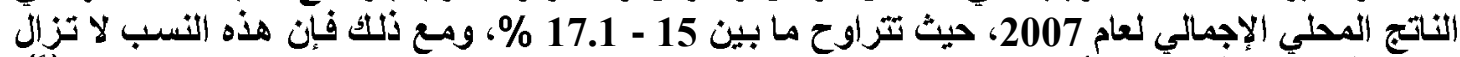

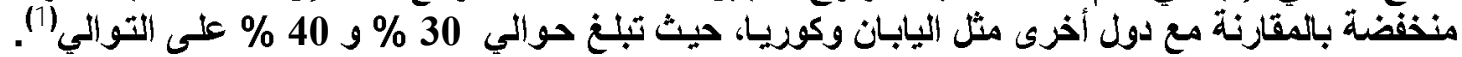

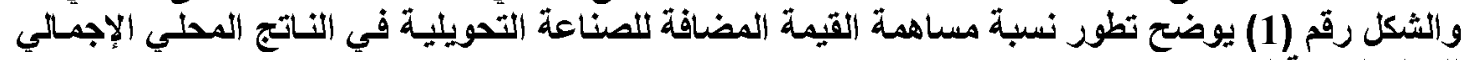
اللاول العزبية لعام 2007.

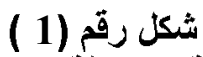

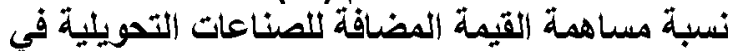

الناتج المحلي الإجمالي في الأول العربية عام 2007

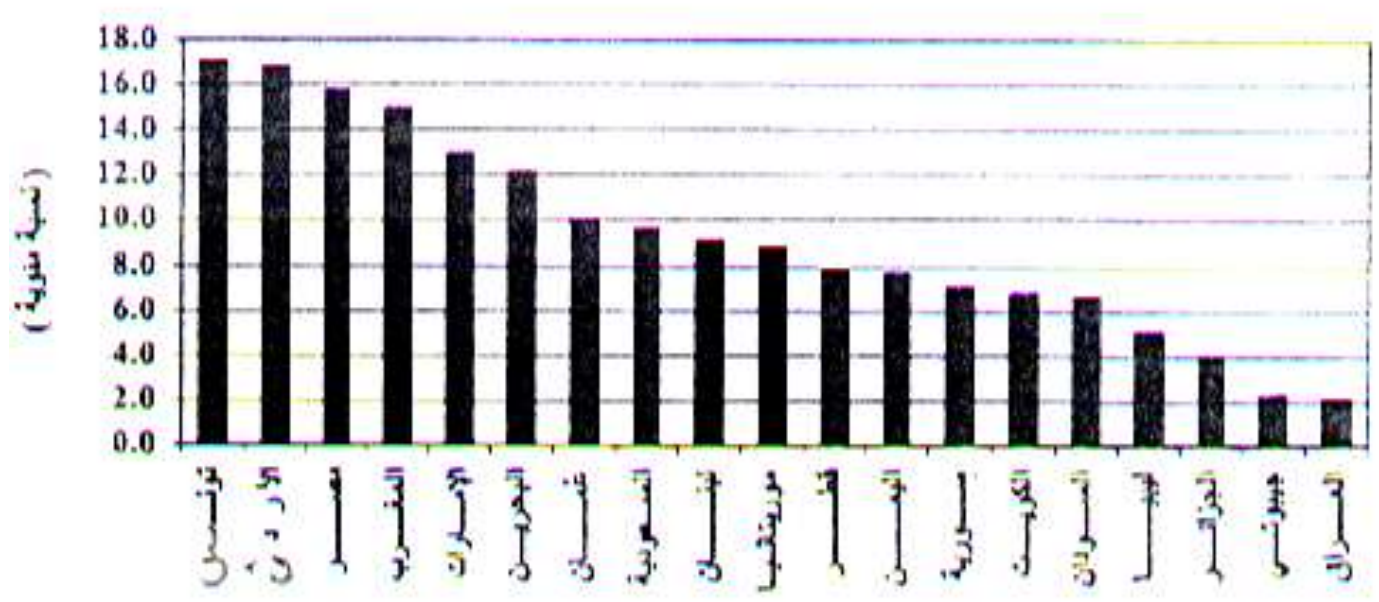

المصدر: التقريز الاقتصادي العزبي الموحد لسنة 2008.

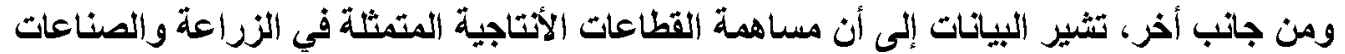

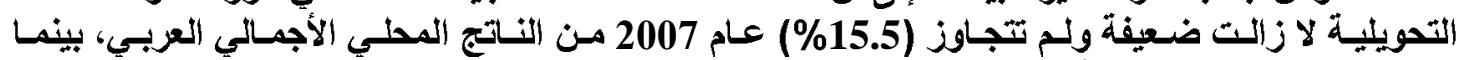

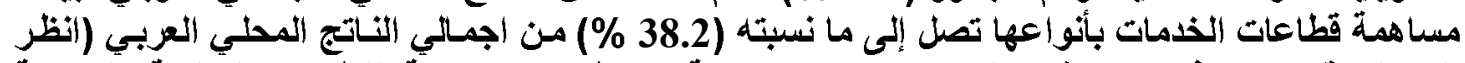

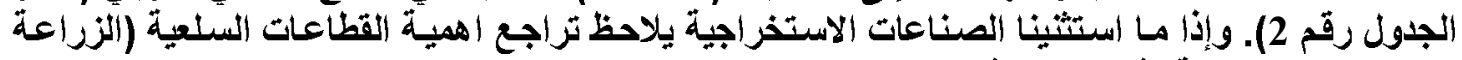

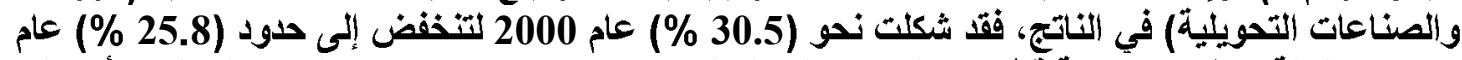

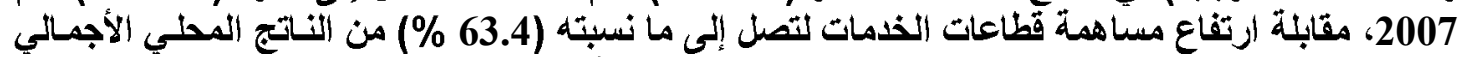

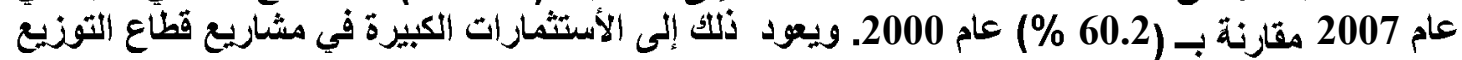

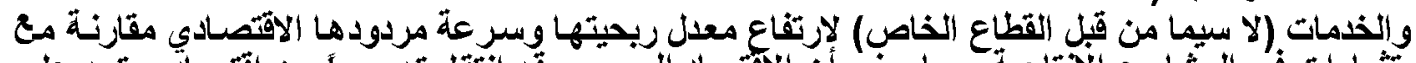

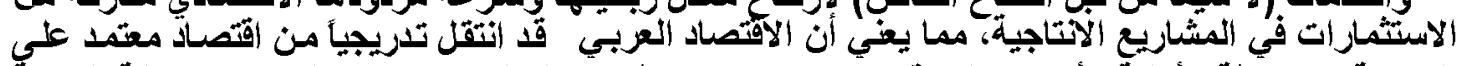

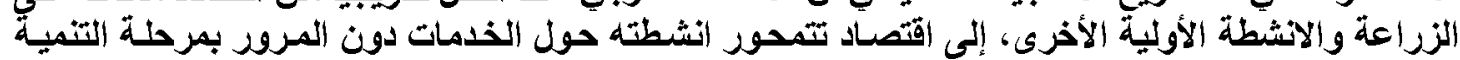

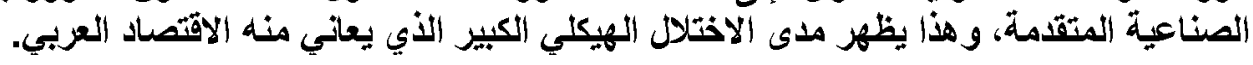


الهيكل القطاعي للناتج المحلي الأجمالي للاول العربية

لعامي 2000 ، 2007

(نسب مئوية)

\begin{tabular}{|c|c|c|c|c|}
\hline \multicolumn{2}{|c|}{ 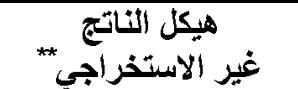 } & \multicolumn{2}{|c|}{ المحلي الأجمالكي * الناتج } & \multirow[t]{2}{*}{ اللييانات } \\
\hline 2007 & 2000 & 2007 & 2000 & \\
\hline 36.6 & 39.8 & 61.8 & 55.8 & ـ قطاعات الإتتاج السلعي منها: \\
\hline 10.1 & 15.6 & 6.1 & 11.5 & 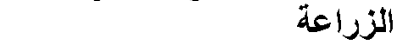 \\
\hline- & - & 39.8 & 26.7 & الصناعات الاستخراجية \\
\hline 15.7 & 14.9 & 9.4 & 10.9 & الصناعات التحويلية \\
\hline 10.8 & 9.3 & 6.5 & 6.7 & باقي قطاعات الانتاج \\
\hline 63.4 & 60.2 & 38.2 & 44.2 & قطاعات الخدمات منها: \\
\hline 16.7 & 16.8 & 10.1 & 12.3 & الخذماًت الحكومبة \\
\hline 100.0 & 100.0 & 100.0 & 100.0 & الناتج المحلي الاجمالي \\
\hline
\end{tabular}

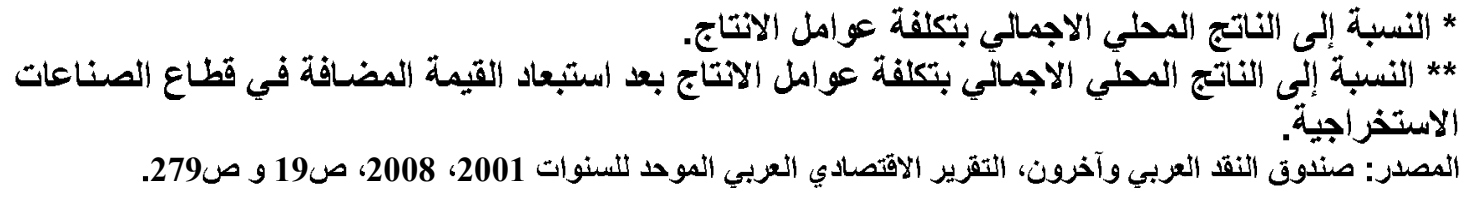

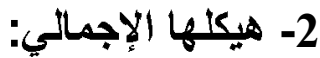

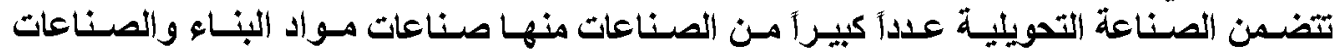

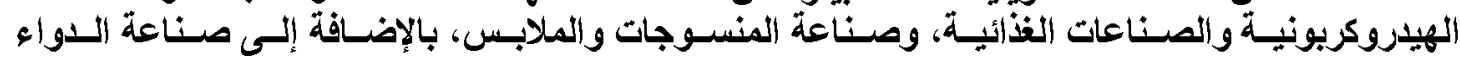

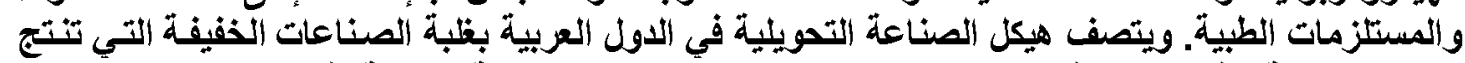

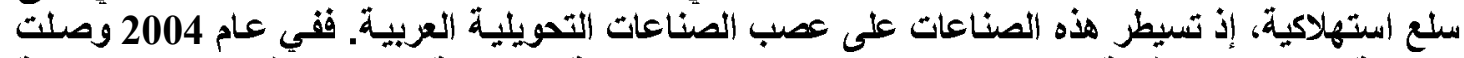

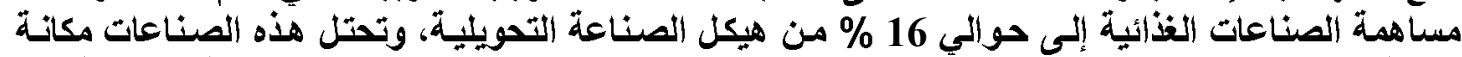

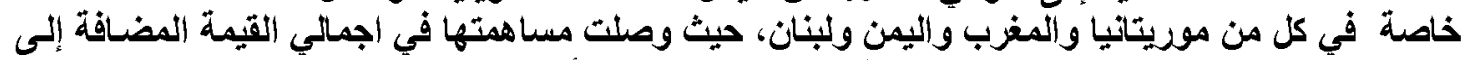

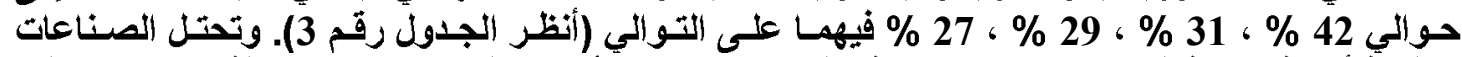

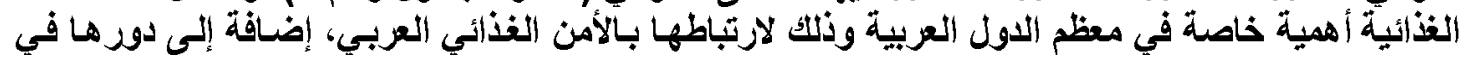

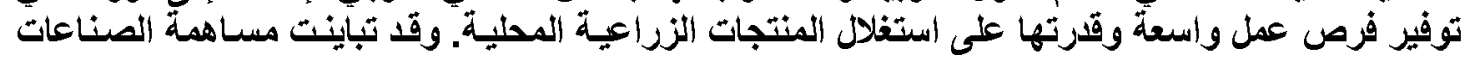

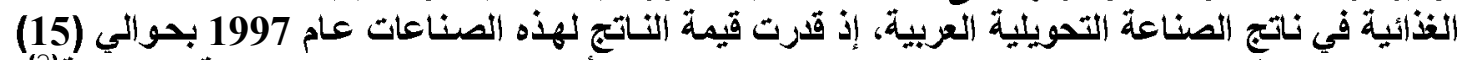

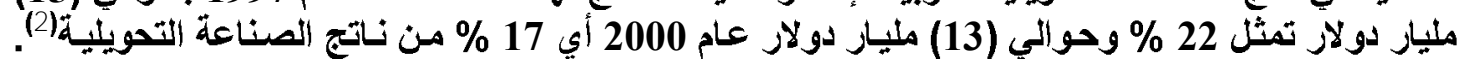

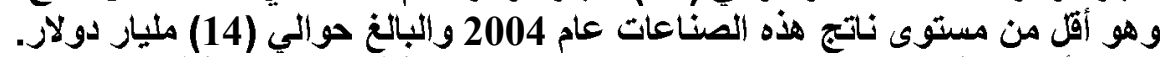

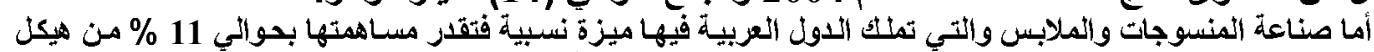

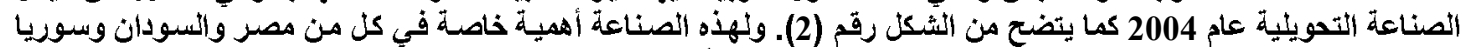

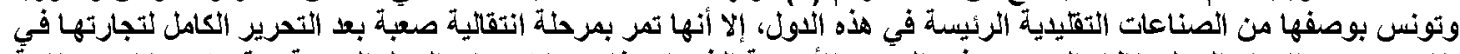

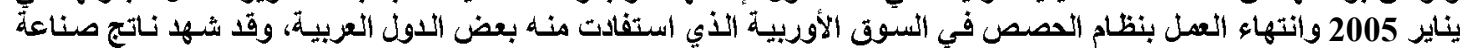

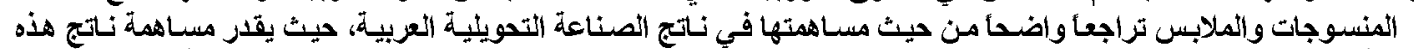

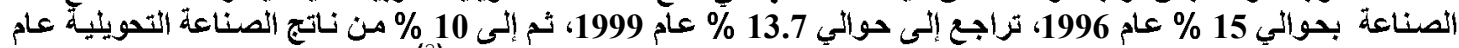

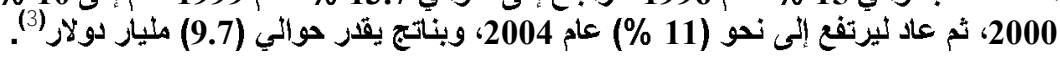




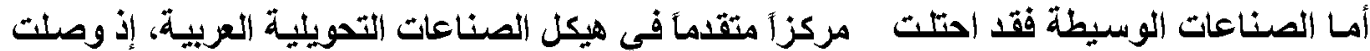

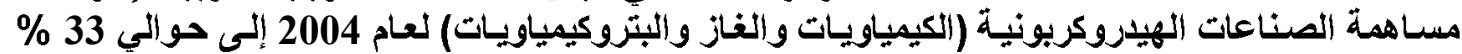

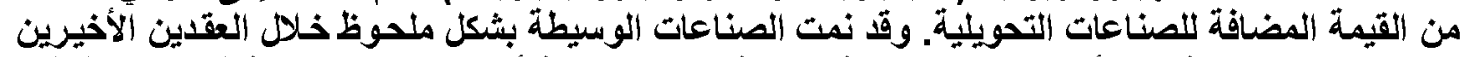

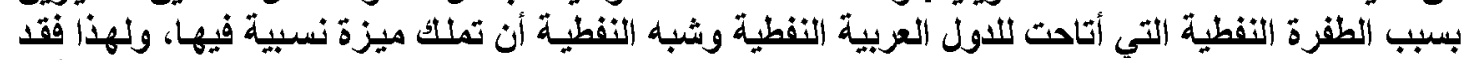

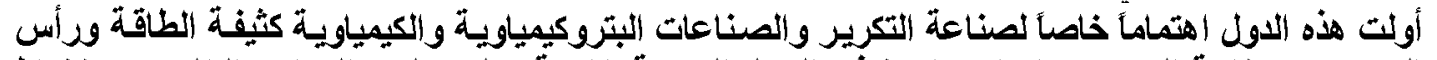

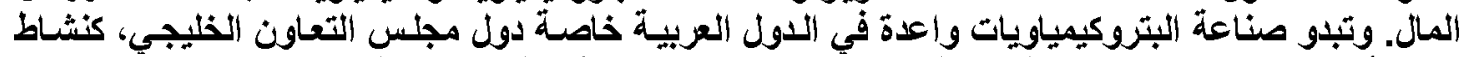

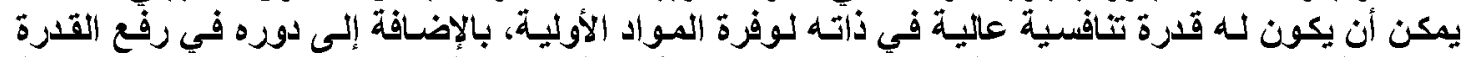

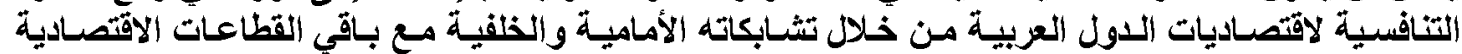

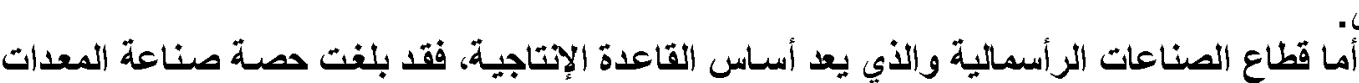
الأخرى.

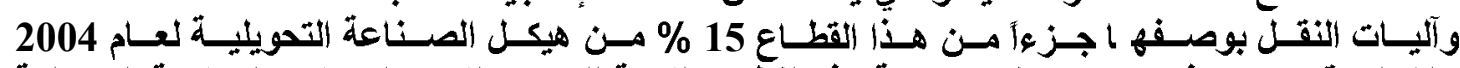

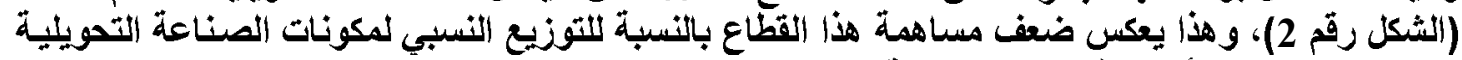

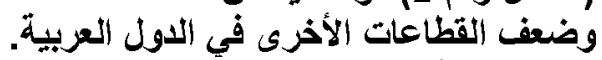

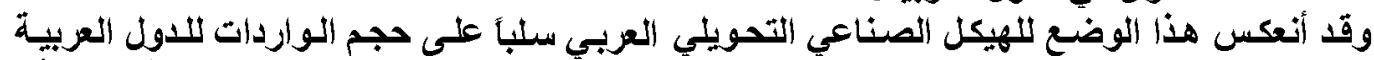

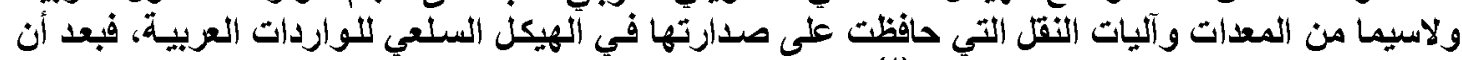

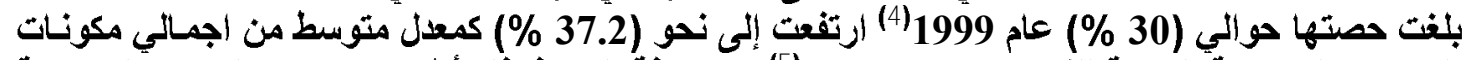

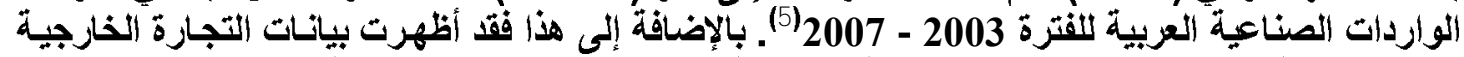

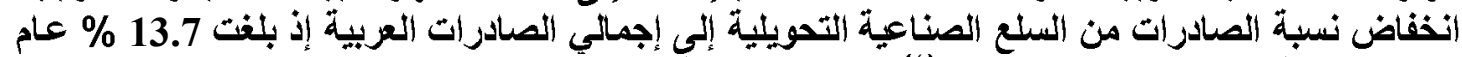

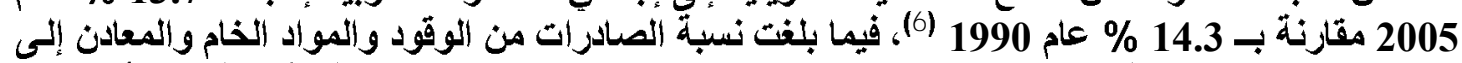

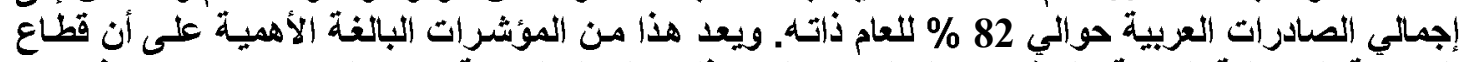

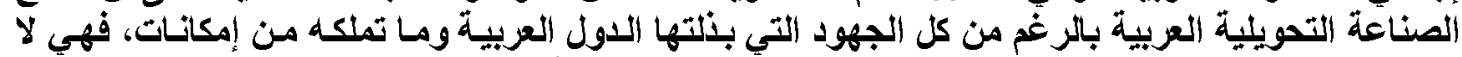

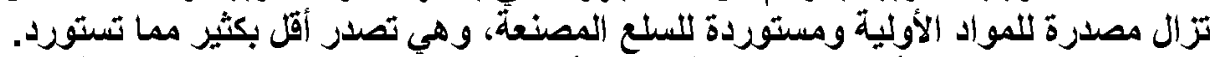

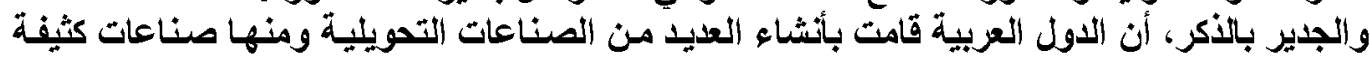

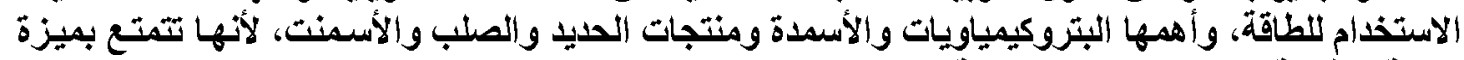
نسبية تناقسية كبيرة بسبب تدني تكلفة مدخلاتها. 


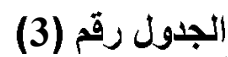

توزيع القيمة المضافة للصناعات التحويلية حسب الأنشطة

الصناعية للاول العربية لعام 2004

(نسبة مئويةة)

\begin{tabular}{|c|c|c|c|c|c|c|c|}
\hline الجمانئي & الأصناعات الأخزى & المعات وآليات & الهيدروكزيونية & والمنسوجاتة & التذائية اعنات & (القيمة المضافة & \\
\hline 100 & 25 & 15 & 33 & 11 & 16 & 87.785 .5 & الألاولية \\
\hline 100 & 34 & 8 & 30 & 6 & 22 & 1.876 .2 & الأردن \\
\hline 100 & 15 & 14 & 51 & 11 & 9 & 13.042 .1 & الإمارات \\
\hline 100 & 73 & 2 & 15 & 3 & 7 & 1.128 .4 & البحرين \\
\hline 100 & 17 & 10 & 25 & 30 & 18 & 5.197.7 & تونس \\
\hline 100 & 48 & 14 & 11 & 7 & 20 & 4.184.1 & الجزائر \\
\hline- & - & - & - & - & - & 15.01 & جيبوتي \\
\hline 100 & 31 & 18 & 38 & 1 & 12 & 25.323 & السعودية \\
\hline- & - & - & - & - & - & 1.204 .5 & ألسودان \\
\hline 100 & 26 & 26 & 2 & 25 & 21 & 718.6 & سوريا \\
\hline- & - & - & - & - & - & 651.2 & الكعراق \\
\hline 100 & 25 & 15 & 28 & 11 & 21 & 2.020 & عُمَنان \\
\hline 100 & 18 & 13 & 45 & 18 & 6 & 1.789 & قطز \\
\hline 100 & 11 & 3 & 76 & 3 & 7 & 4.457 & الكويت \\
\hline 100 & 33 & 17 & 8 & 15 & 27 & 1.794 .9 & لبنان \\
\hline- & - & - & - & - & - & 925.4 & كيبيا \\
\hline 100 & 18 & 21 & 27 & 15 & 19 & 13.537 .9 & مصر \\
\hline 100 & 18 & 21 & 27 & 15 & 19 & 9.187 .7 & ألمغرب \\
\hline 100 & 20 & 20 & 15 & 3 & 42 & 155.0 & موريتانيا \\
\hline 100 & 42 & 10 & 14 & 5 & 29 & 577.0 & اليمن \\
\hline
\end{tabular}

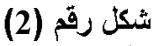

(سبتمبر) 2005، ص286.

التوزيع النسبي لمصادر القيمة المضافة لقطاع الصناعات التحويلية في الاول العزبية عام 2004

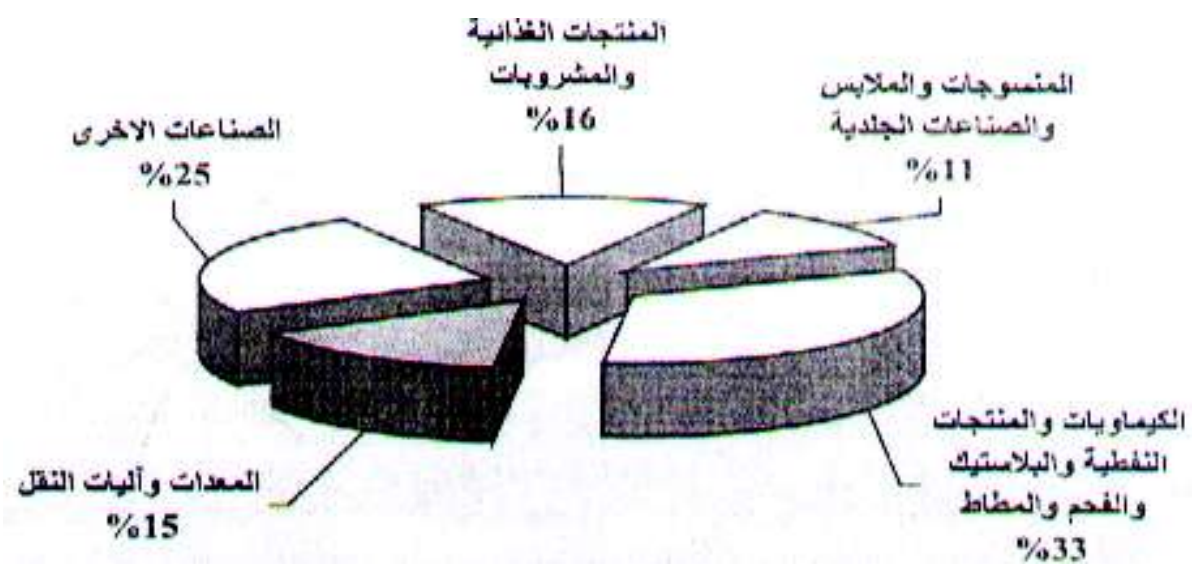

المصدر: استتادًا إلى بيانات الجدول رقم (3) 


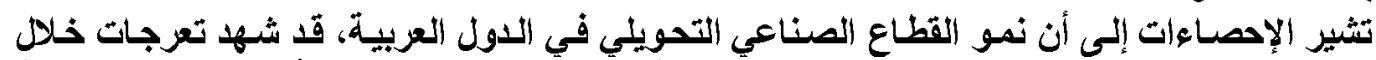

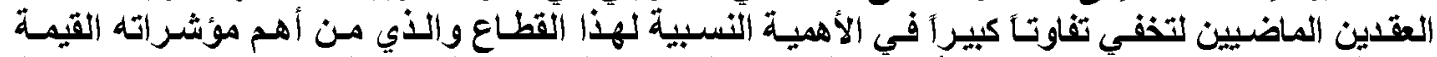

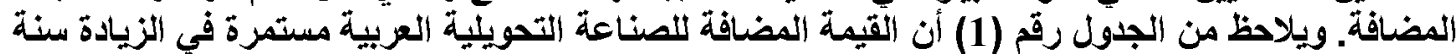

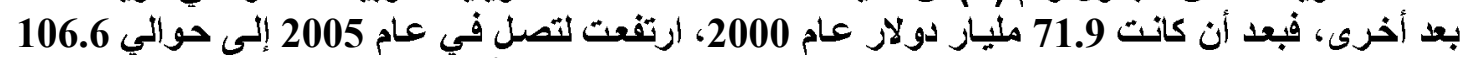

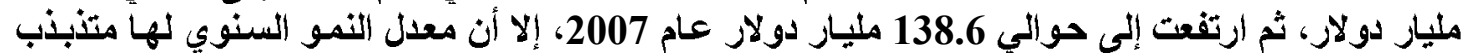

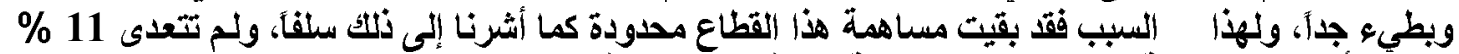

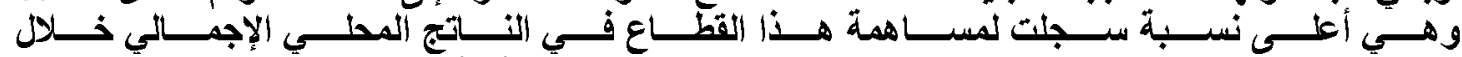

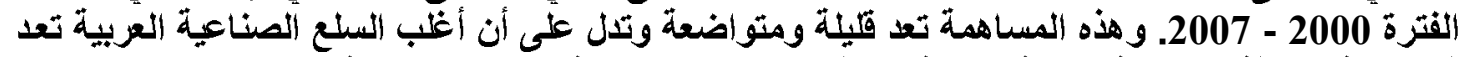

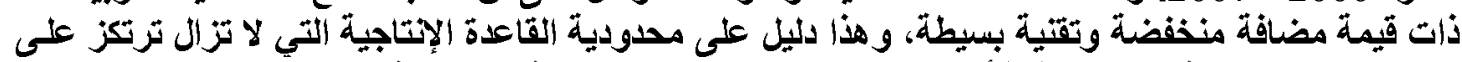

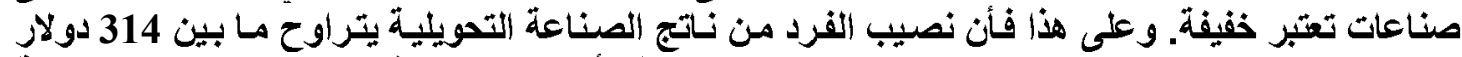

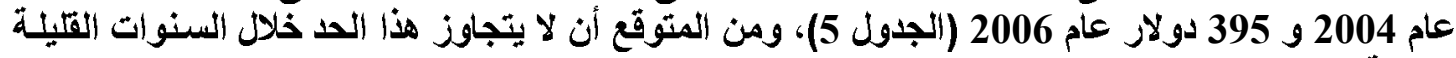
القادمة.

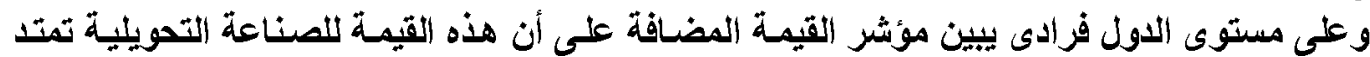

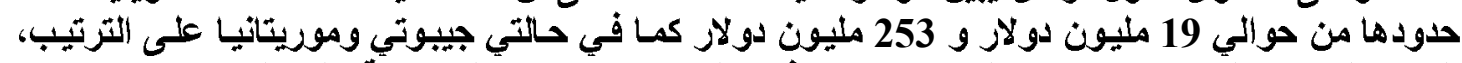

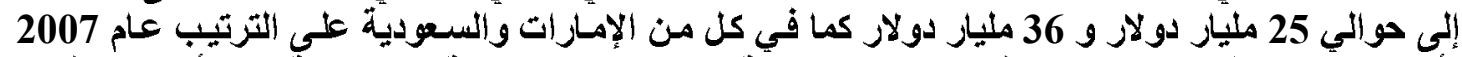

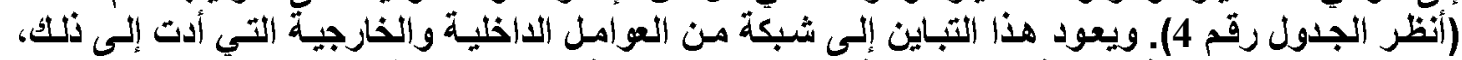

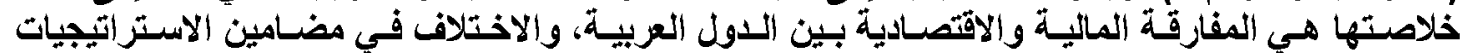

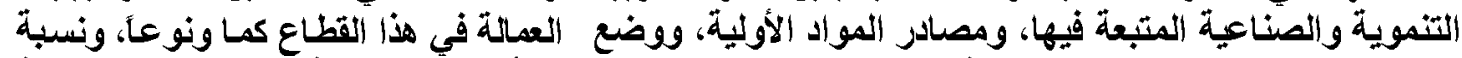

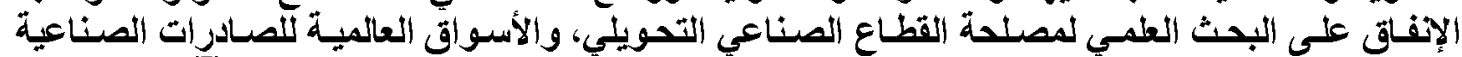

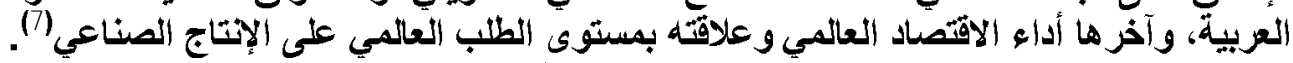

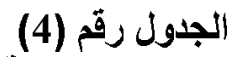

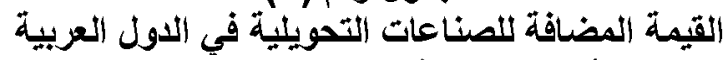

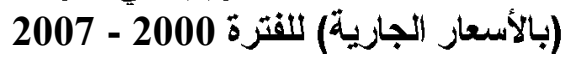

(مليون دولار)

\begin{tabular}{|c|c|c|c|c|c|c|c|c|}
\hline 2007 & 2006 & 2005 & 2004 & 2003 & 2002 & 2001 & 2000 & \\
\hline 138.588 .4 & 120.912 .8 & 106.592 & 93.918.6 & 82.611 .6 & 74.743 .4 & 72.964 .4 & 71.836 .9 & العريبة \\
\hline 2.665 .3 & 2.393 .2 & 2.051 .8 & 1.852 .8 & 1.526 .9 & 1.393 .1 & 1.214 .7 & 1.138 .6 & الأردن \\
\hline 24.994.1 & 19.995 .4 & 16.665 .8 & 13.658 .0 & 11.494 .9 & 10.268 .2 & 9.566 .2 & 9.465 .4 & الإمارات \\
\hline 2.260 .2 & 1.951 .3 & 1.615 .1 & 1.215 .5 & 1.118 .0 & 1.019 .7 & 926.5 & 888.8 & البحرين \\
\hline $\begin{array}{l}5.908 .7 \\
\end{array}$ & 1.410 .3 & 4.974 .9 & $\begin{array}{l}5.195 .7 \\
\end{array}$ & 4.836 .3 & 4.302 .2 & 3.716.1 & 3.530.7 & تونس \\
\hline 5.378.6 & 4.537.1 & 4.347 .8 & 4.185 .5 & 3.658 .2 & 3.456.0 & 3.323.1 & 3.188.1 & الجزائر \\
\hline 18.6 & 17.2 & 16.0 & 15.0 & 14.1 & 13.4 & 13.0 & 12.6 & جيبوتي \\
\hline 36.267 .5 & \begin{tabular}{|l|}
33.043 .2 \\
\end{tabular} & 29.522 .9 & 25.554 .1 & \begin{tabular}{|l|l|}
23.004 .8 \\
\end{tabular} & \begin{tabular}{|l|l|}
19.460 .0 \\
\end{tabular} & 18.454 .9 & 18.210 .7 & |السعودية \\
\hline 3.778 .5 & 3.280 .6 & 2.477 .2 & 2.131 .9 & 1.635 .3 & 1.467 .0 & 1.251 .5 & 882.1 & السودان \\
\hline 2.883.1 & 2.360 .4 & 205.7 & 2.329 .9 & 1.770 .9 & 1.654 .5 & 1.742 .3 & 780.7 & سوريا \\
\hline 1.448 .8 & 982.1 & 784.4 & 514.0 & 156.9 & 319.0 & 316.1 & 236.3 & الكراق \\
\hline 4.051.8 & 3.697 .5 & 2.556 .8 & 2.086 .3 & 1.872 .3 & 1.640 .3 & 1.659 .8 & 1.078 .2 & عَمان \\
\hline 4.957.1 & 4.361 .3 & 3.585 .0 & 3.295 .3 & 1.800 .3 & 1.394 .5 & 1.073 .9 & 965.7 & قطر \\
\hline 5.572 .7 & 5.563 .4 & 5.806 .1 & $\begin{array}{l}4.940 .3 \\
\end{array}$ & 3.781 .6 & 2.984 .8 & 2.212 .4 & 2.607 .9 & أكويت \\
\hline 2.236 .2 & 2.068 .5 & 1.958 .8 & 1.950 .4 & 1.798 .9 & 1.700 .2 & 1.550 .6 & 1.515 .5 & لبنان \\
\hline 3.124 .0 & 2.753 .4 & 2.390 .6 & 1.883 .6 & 1.552 .3 & 1.164 .9 & 1.967 .6 & 2.316 .1 & كيبيا \\
\hline 20.102 .0 & $\begin{array}{l}17.155 .0 \\
\end{array}$ & 14.950 .4 & 13.551 .1 & \begin{tabular}{|l|l|}
14.038 .8 \\
\end{tabular} & $\begin{array}{l}15.752 .7 \\
\end{array}$ & 17.707 .7 & 18.362 .5 & مصر مصر \\
\hline \begin{tabular}{|l|l|}
10.980 .9 \\
\end{tabular} & 9.776 .9 & 9.308 .0 & $\begin{array}{l}5.810 .1 \\
\end{array}$ & 7.731 .9 & $\begin{array}{l}6.013 .9 \\
\end{array}$ & 5.602 .6 & 6.029 .1 & ألمغرب \\
\hline 253.1 & 85.5 & 55.5 & 27.0 & 57.4 & 55.3 & 74.2 & 75.7 & هوريتانيا \\
\hline 1.614 .2 & 1.480 .4 & 1.915 .1 & 1.022 .1 & 702.0 & 683.7 & 596.3 & 552.2 & النيمن \\
\hline
\end{tabular}




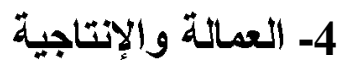

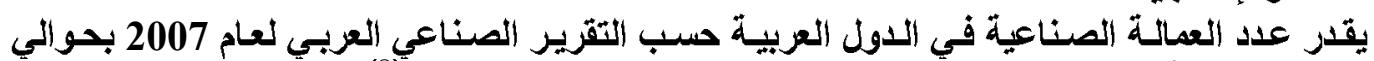

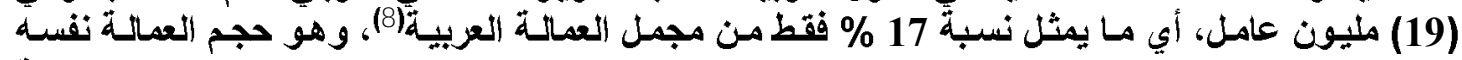

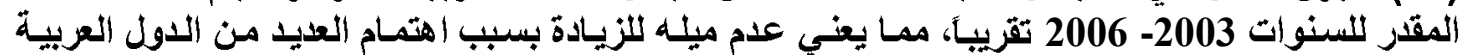

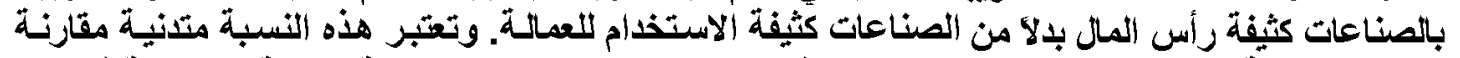

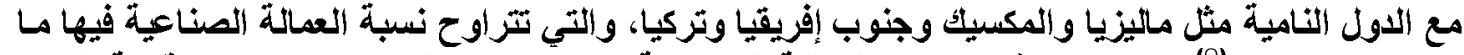

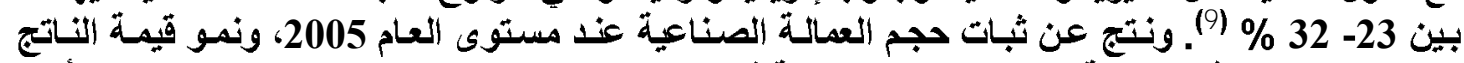

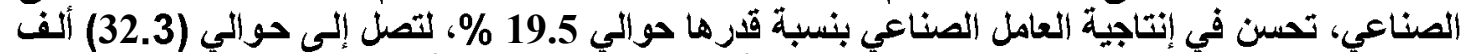

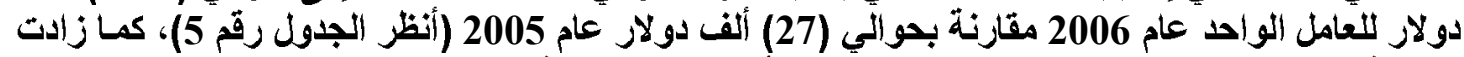

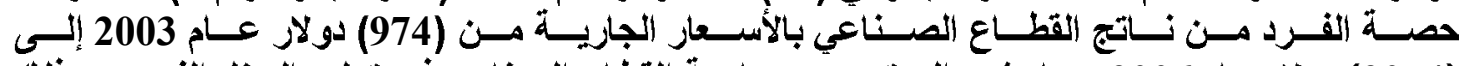

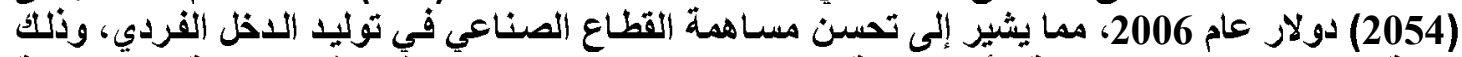

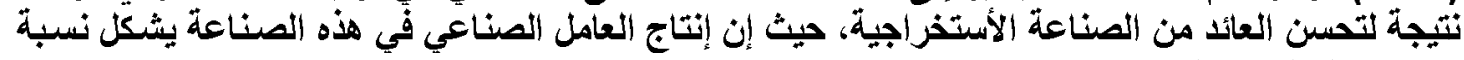

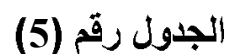

كبيزة تصل إلى حو اللي 70 \%

متوسط نصيب القرد من الناتج الصناعي العربي وإنتاجية العامل الصناعي للفترة 2003 - 2006 (دولار)

\begin{tabular}{|c|c|c|c|c|c|c|}
\hline \multirow{2}{*}{ 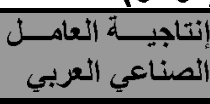 } & \multicolumn{5}{|c|}{ متوسط نصيب الفرد من ناتج القطاع الصناعى } & \multirow[t]{3}{*}{ 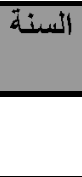 } \\
\hline & القطاع الصناعي & \multicolumn{2}{|c|}{ الصناعة النحويلية } & \multicolumn{2}{|c|}{ الصناعة الأستخراجية } & \\
\hline & & السبنة التفيير & & السبنة التفيير & & \\
\hline 16.007 & 974 & - & 216 & - & 758 & 2003 \\
\hline 20.129 & 1.304 & 45.3 & 314 & 30.2 & 987 & 2004 \\
\hline 27.049 & 1.744 & 11.7 & 351 & 41.1 & 1393 & 2005 \\
\hline 32.341 & 2.054 & 12.5 & 395 & 19.0 & 1658 & 2006 \\
\hline
\end{tabular}

المصدر: صندوق النقا العربي وآخرون، التقريز الاقتصادي العربي الموحد للسنوات 2004 - 2006، 2007.

ثنانيا- أداء الصناعة العربية

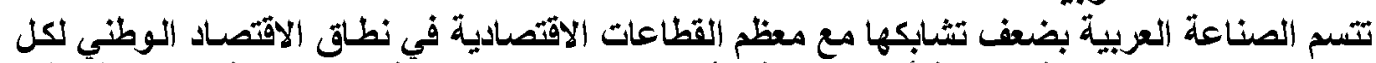

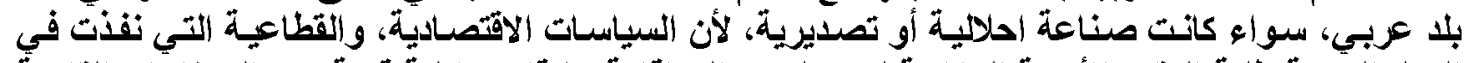

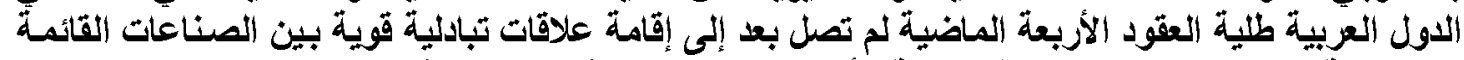

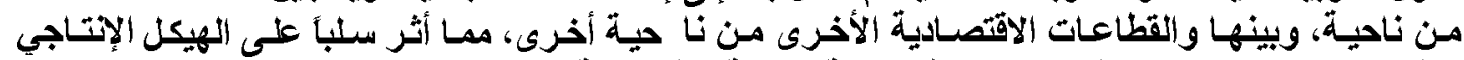

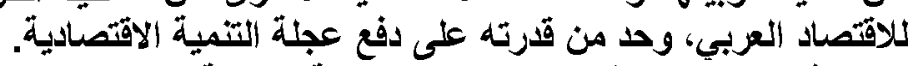

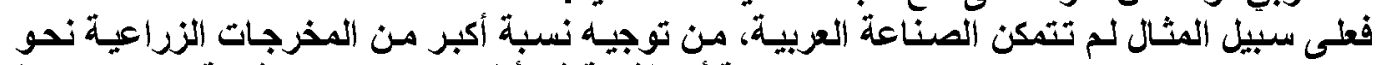

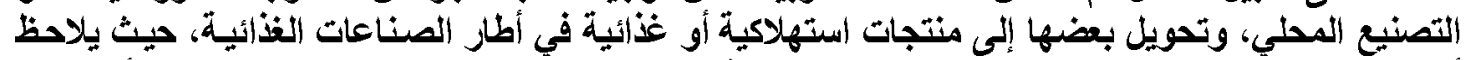

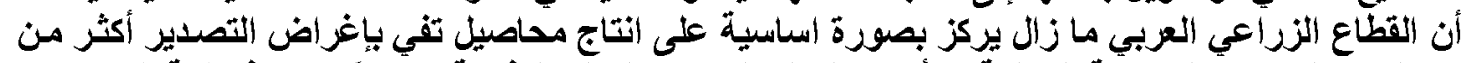

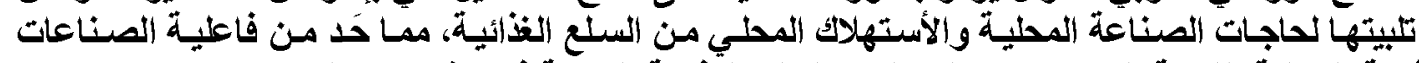

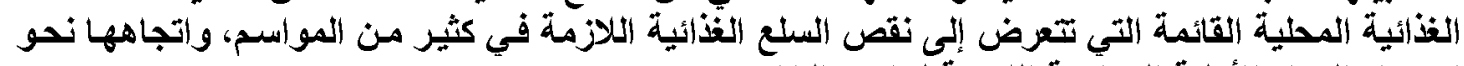

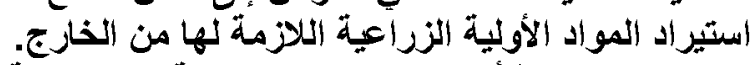

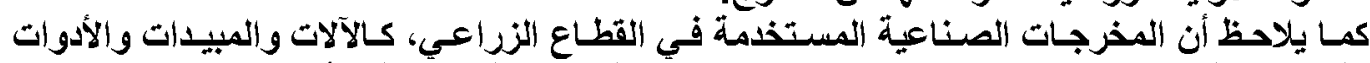

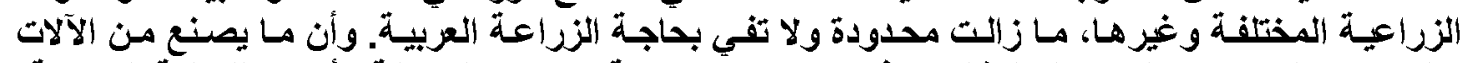

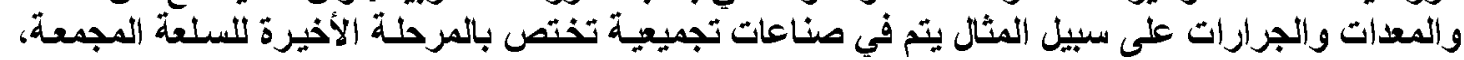

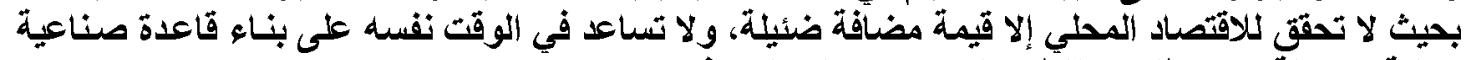

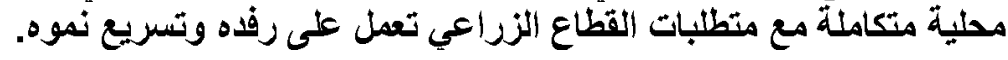




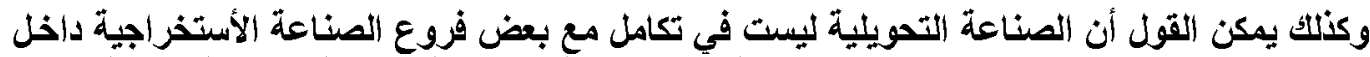

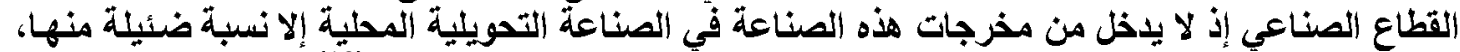

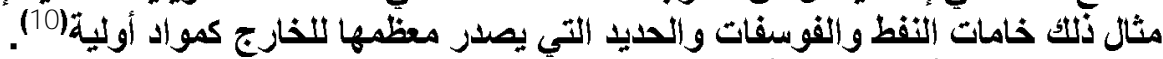

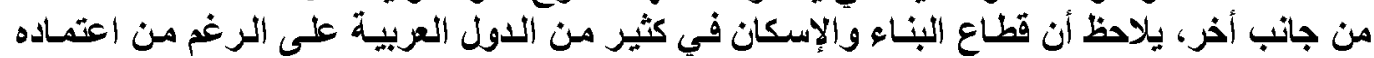

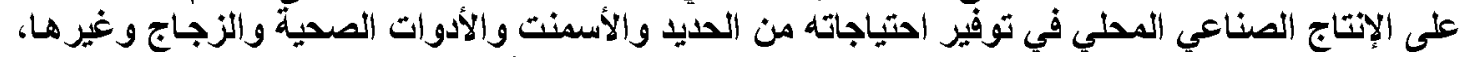

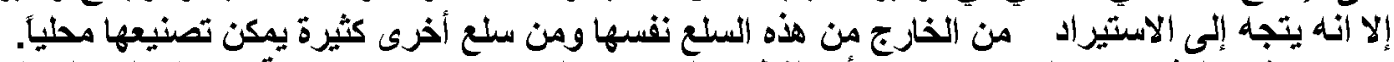

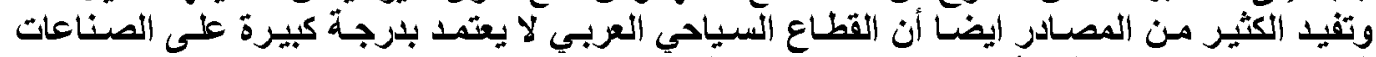

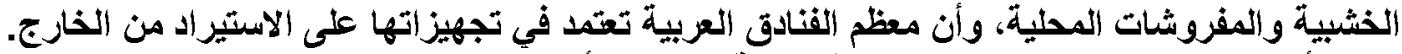

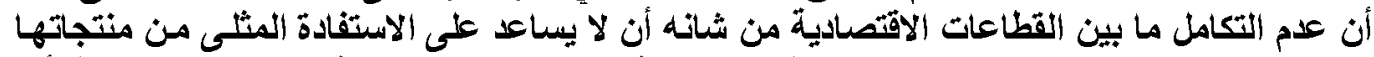

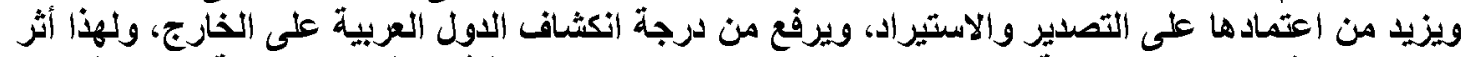

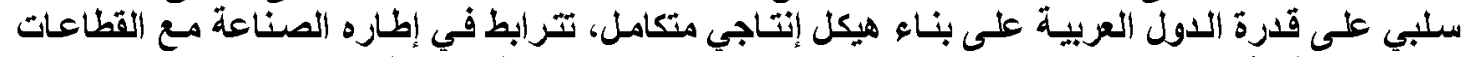

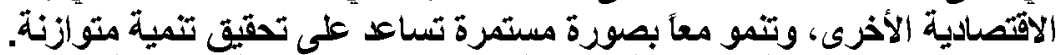

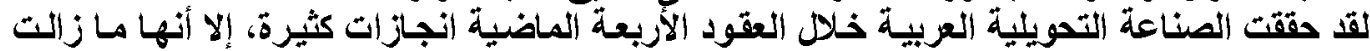

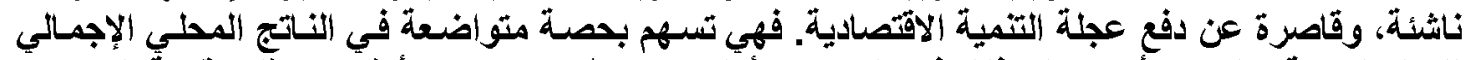

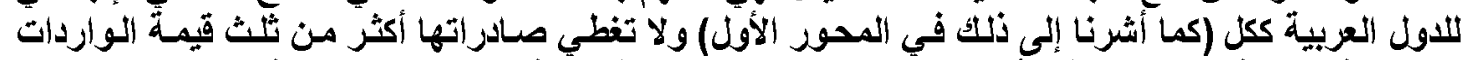

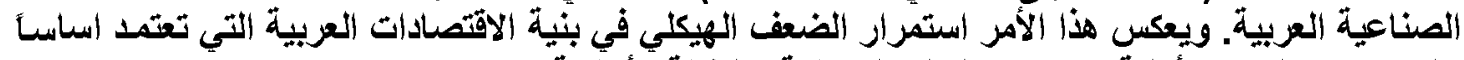

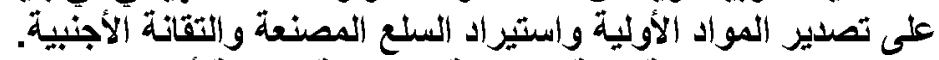

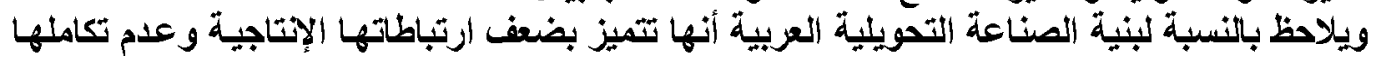

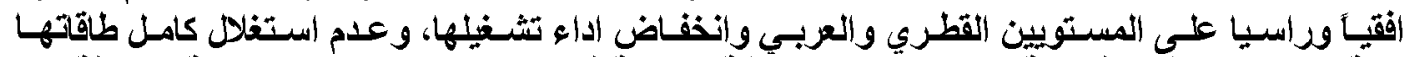

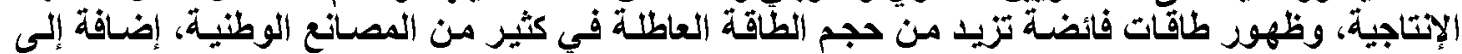

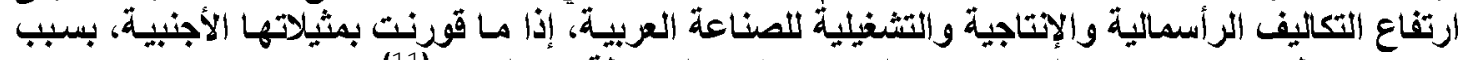

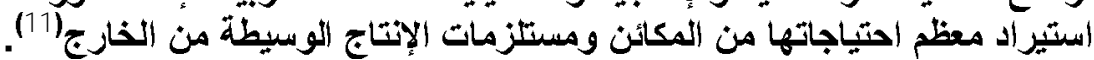

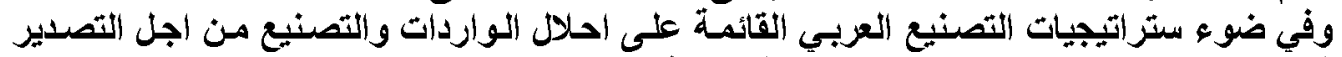

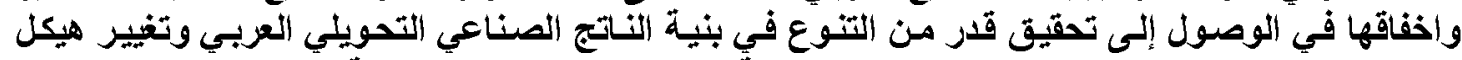

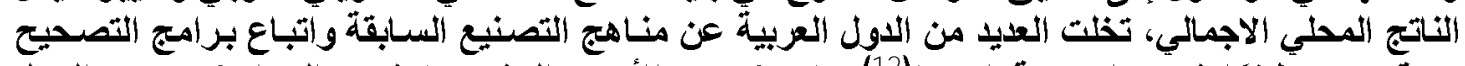

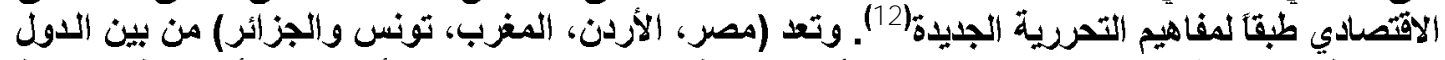

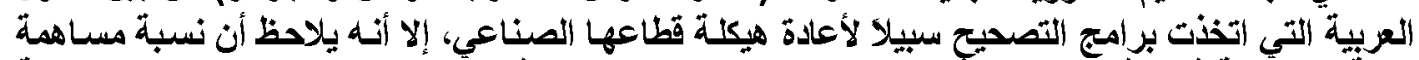

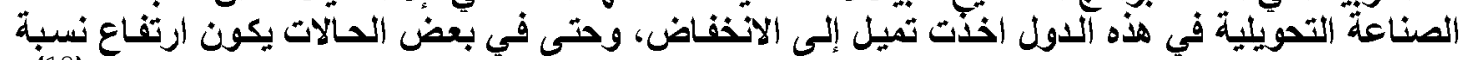

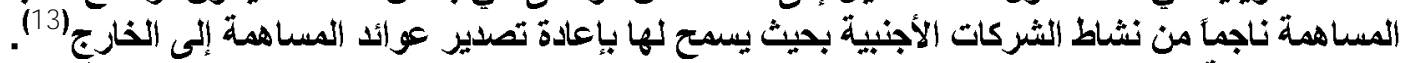

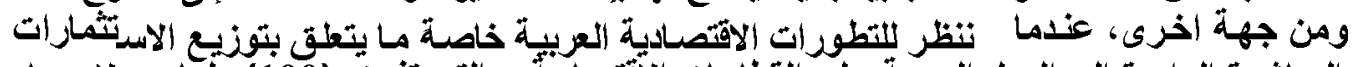

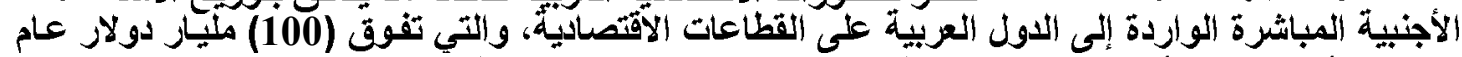

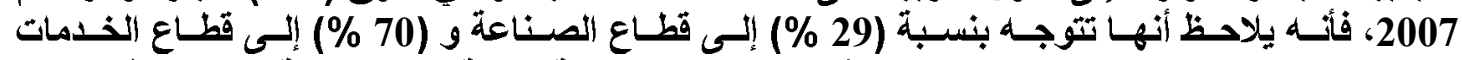

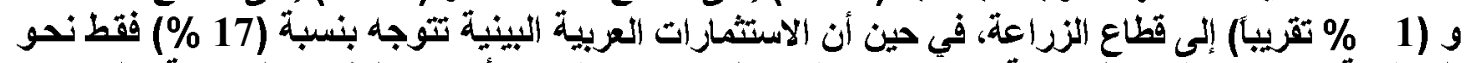

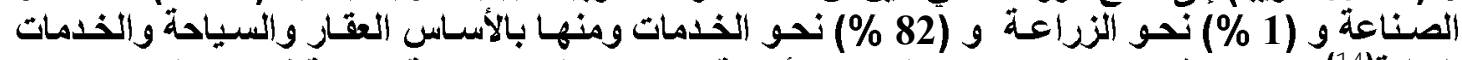

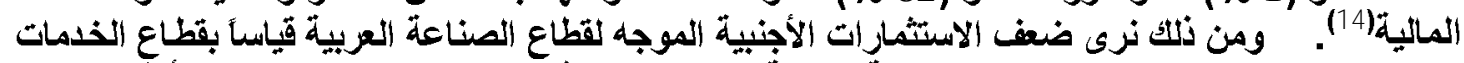

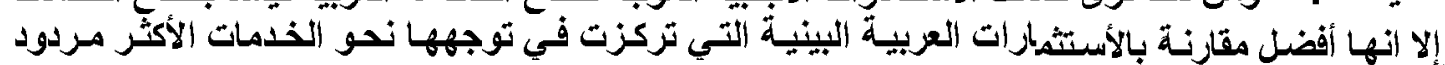


وعموما فأن المؤشر ذو الدالاة الخاص بقصور الصناعة التحويلية العربية يكمن في الأمرين التاليين:

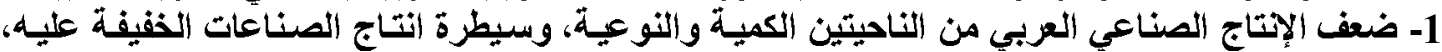

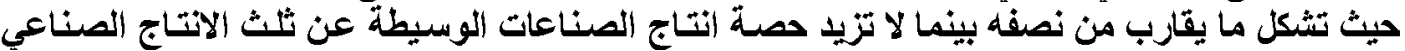

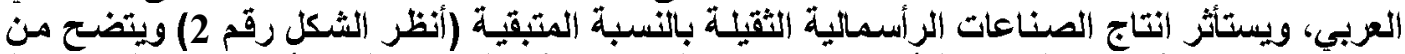

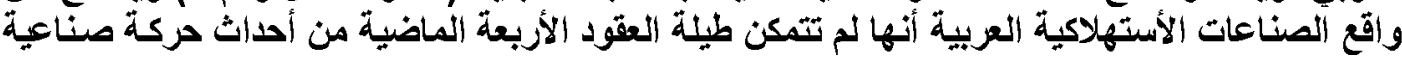

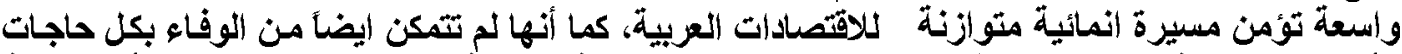

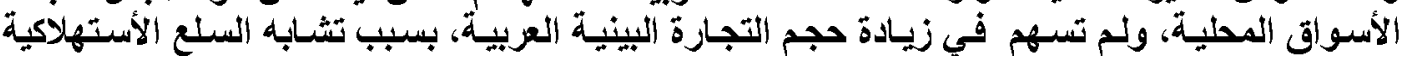
العربية المنتجة محليًا.

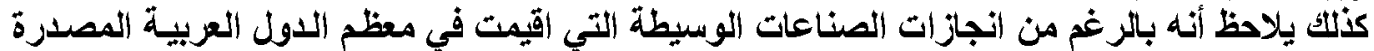

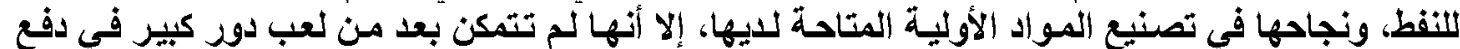

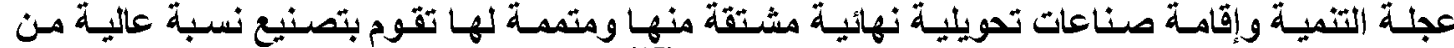

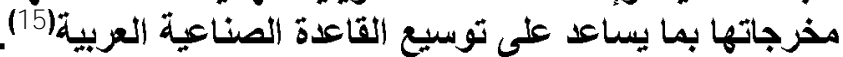

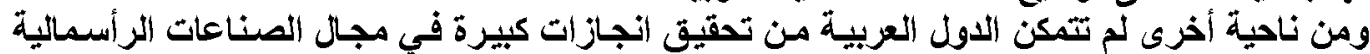

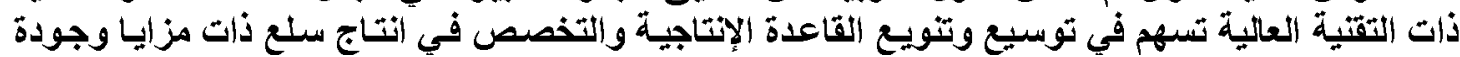

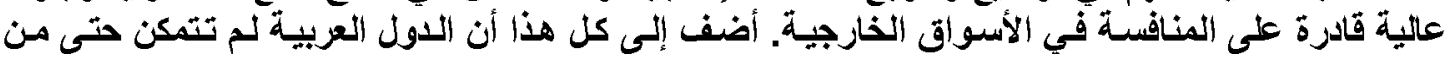

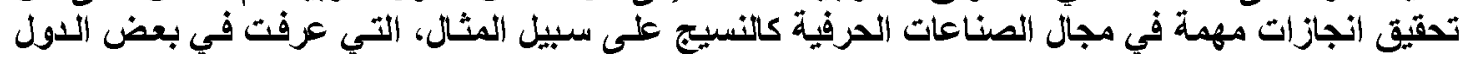

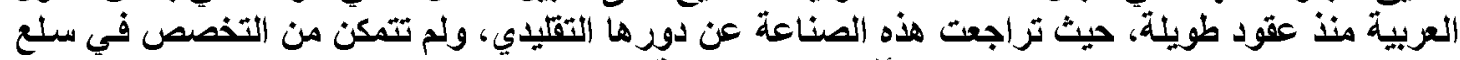

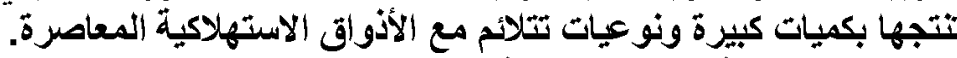

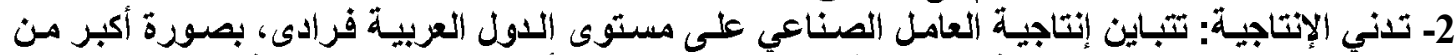

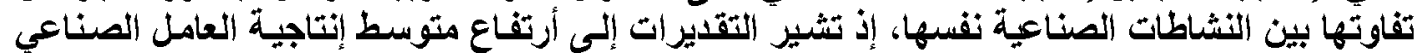

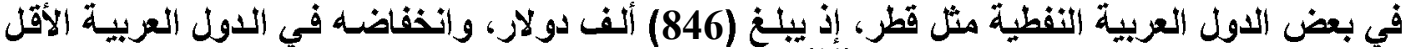

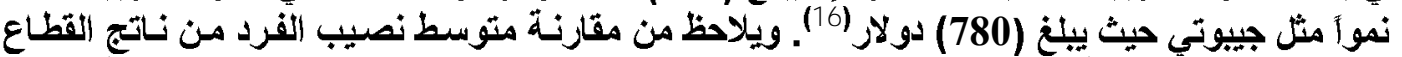

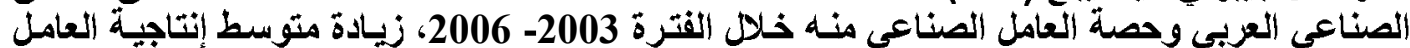

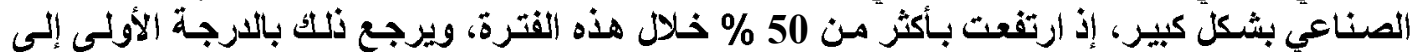

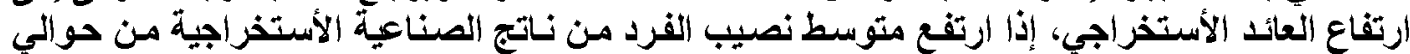

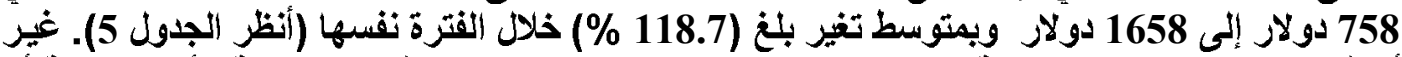

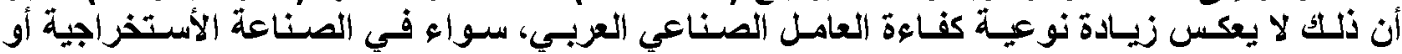

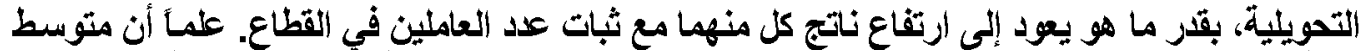

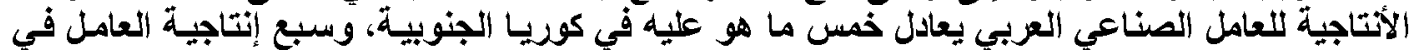

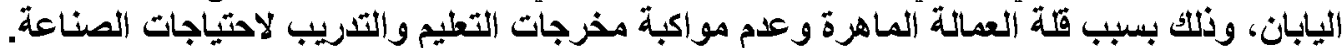

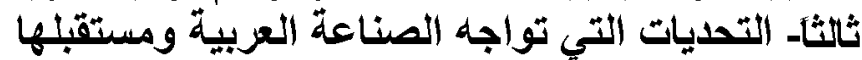

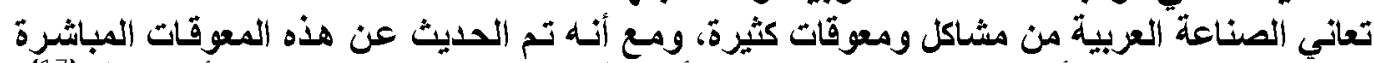

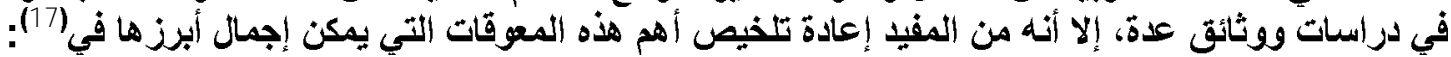

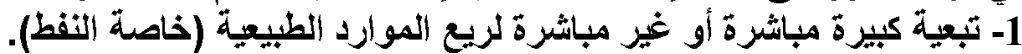

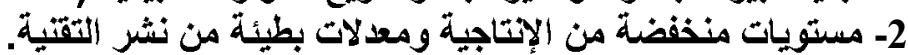

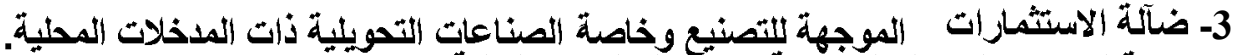

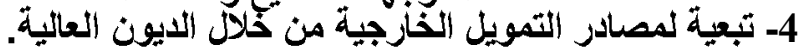

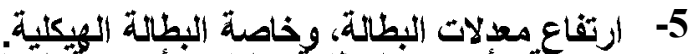

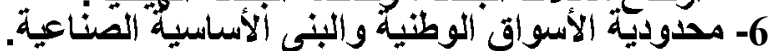




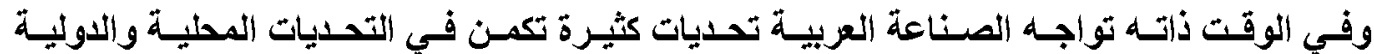

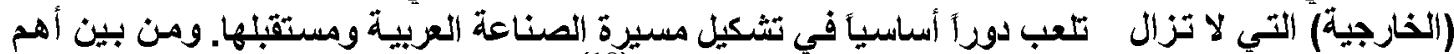

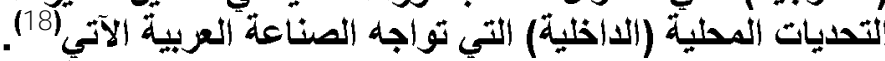

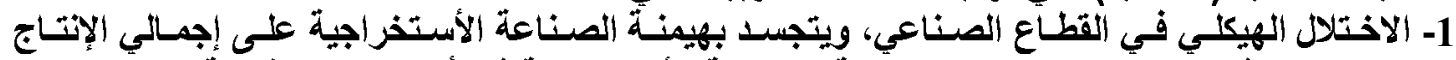

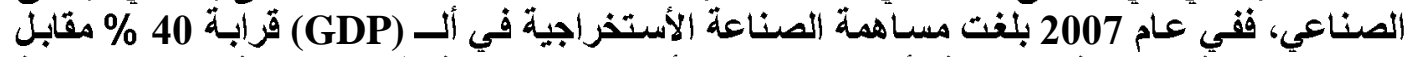

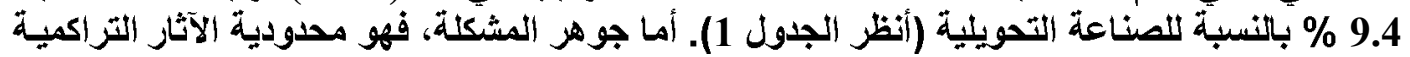

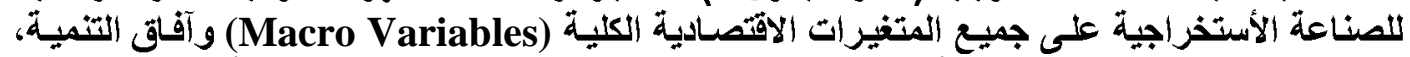

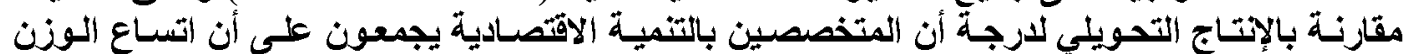

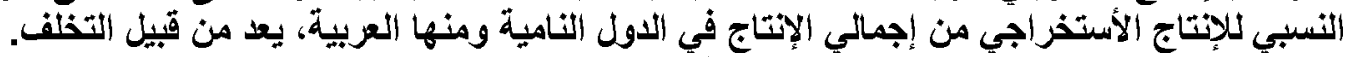

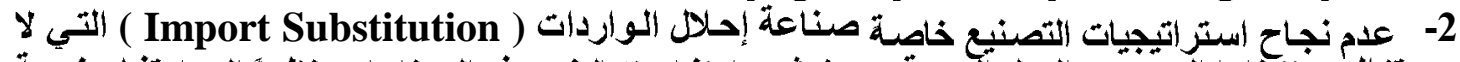

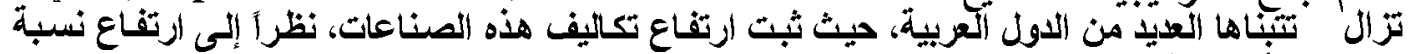

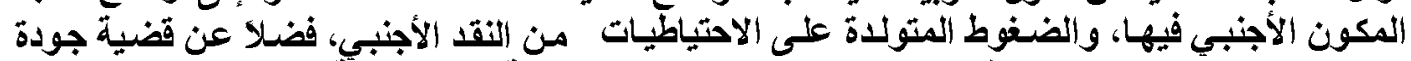

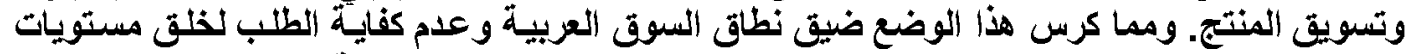

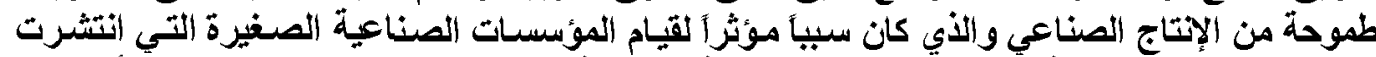

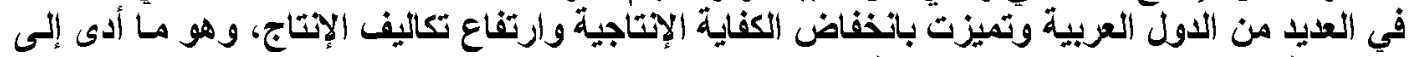

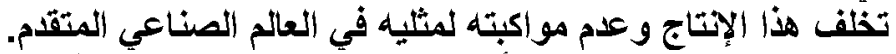

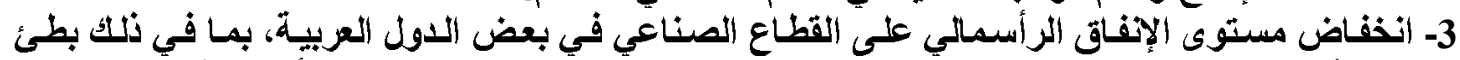

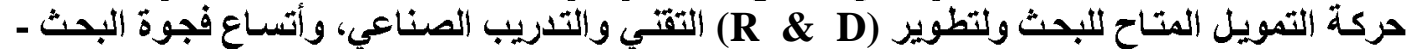

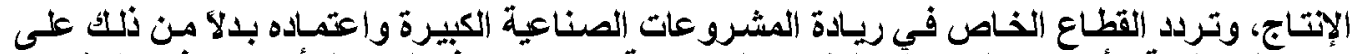

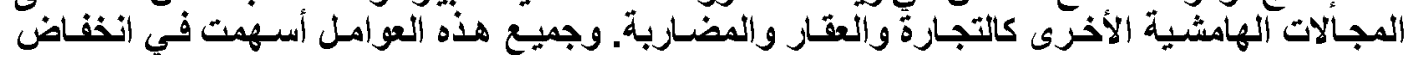

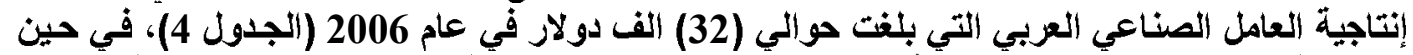

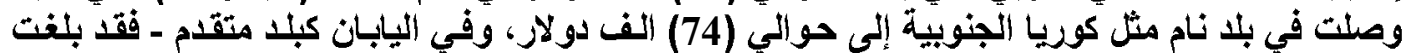

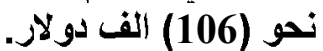

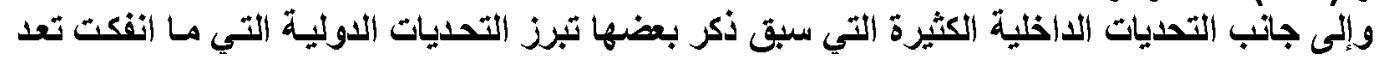

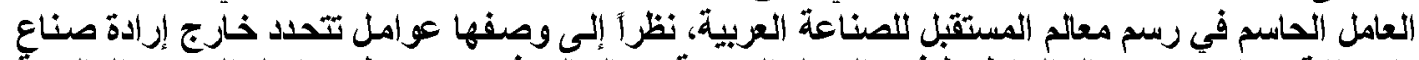

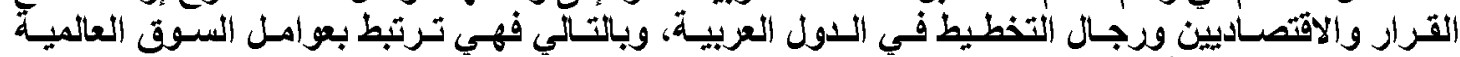

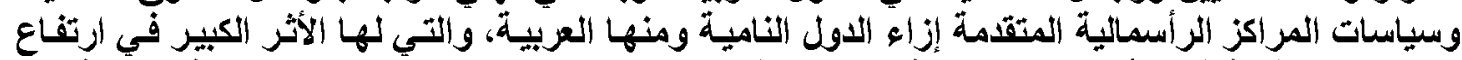

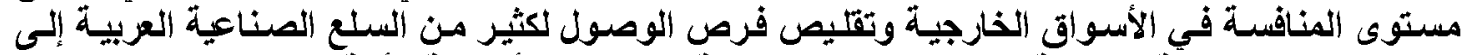

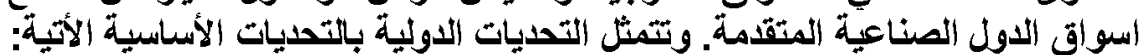

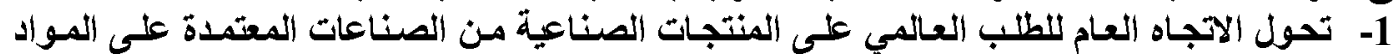

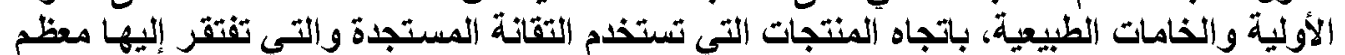

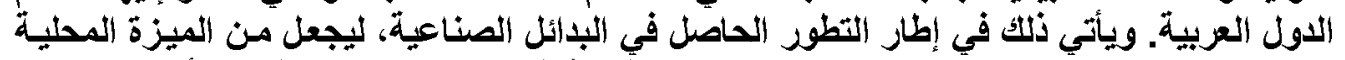

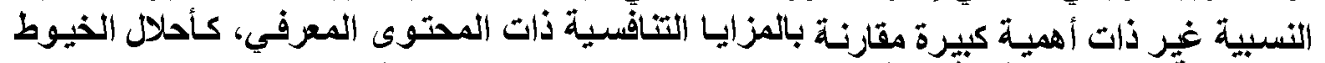

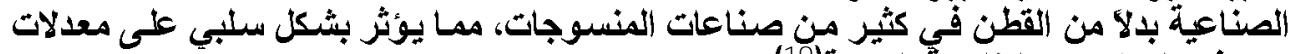

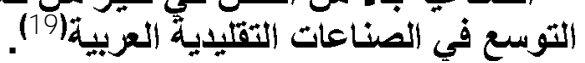

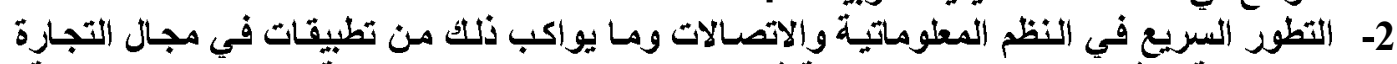

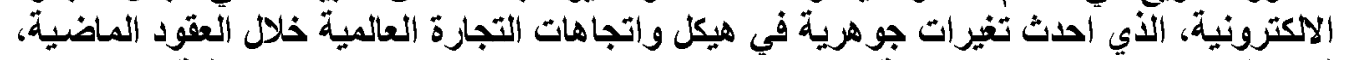

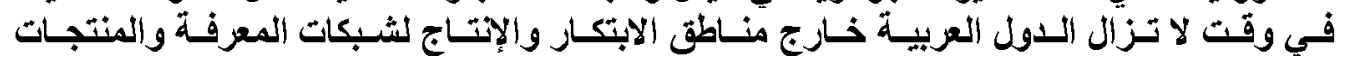

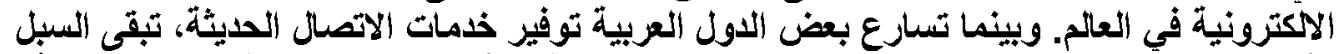

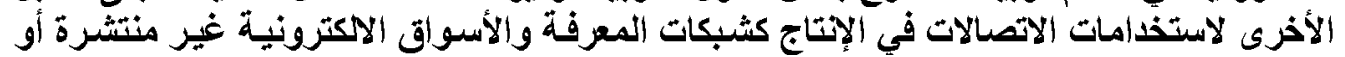

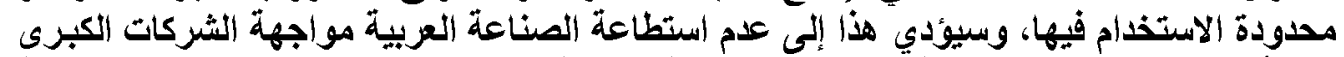

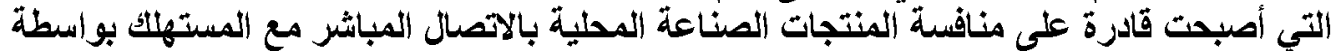

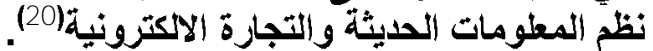


3- ومن أخطر التحديات التى تتظظر الدول العربية في ظل الظروف العالمية الجديدة، هي المفاوضات التى تجري

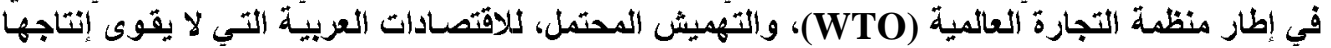

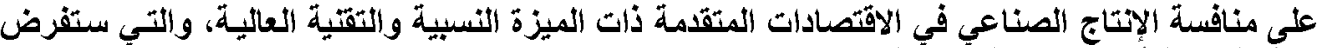

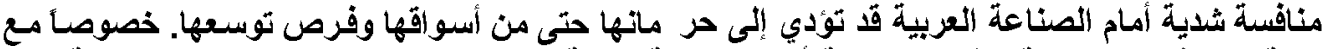

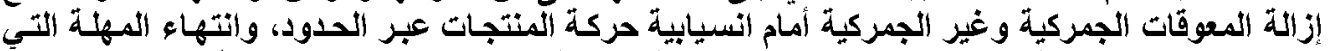

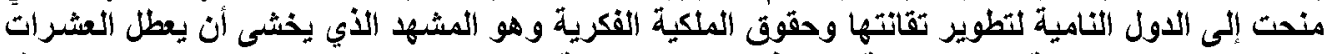

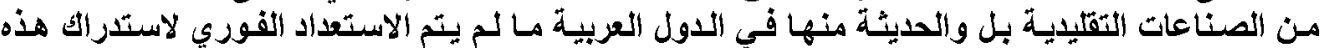

المخاطر (21)

رابعأ التأثيرات المحتملة لتطبيق اتفاقات WTO على الصناعة العربية

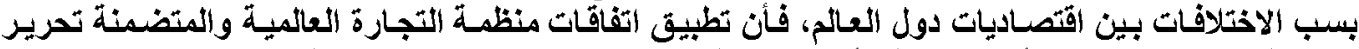

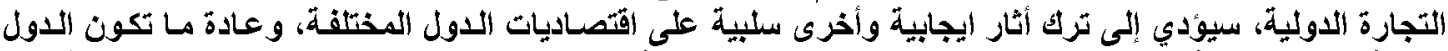

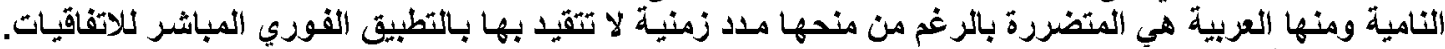

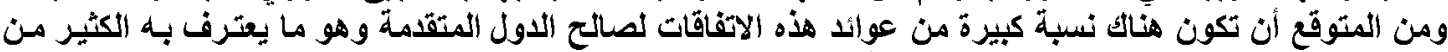

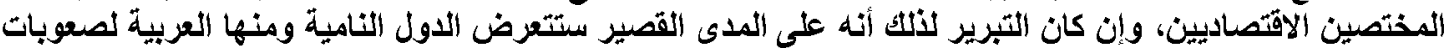

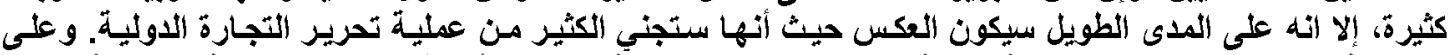

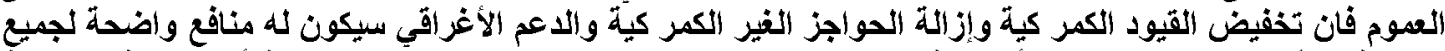

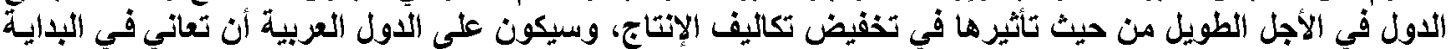

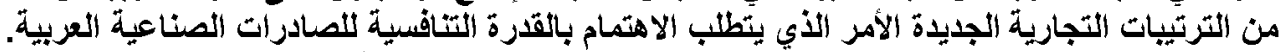

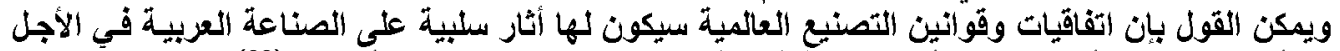

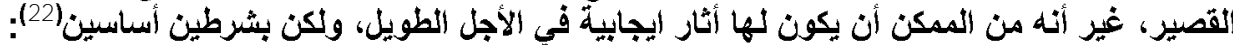

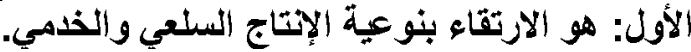

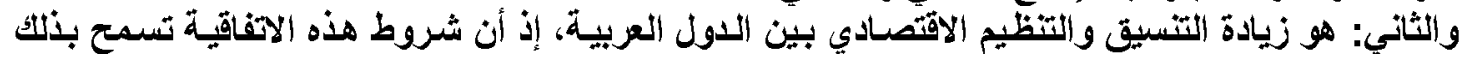

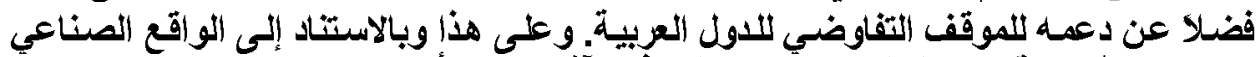

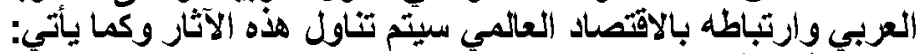

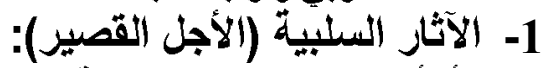

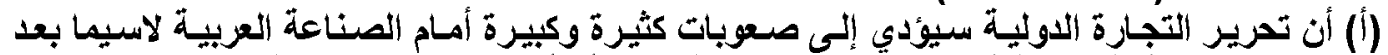

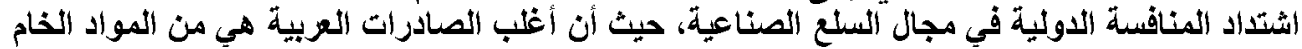

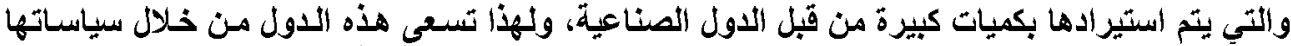

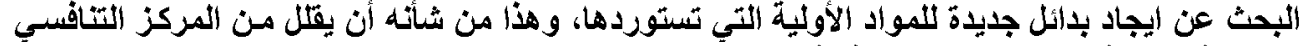

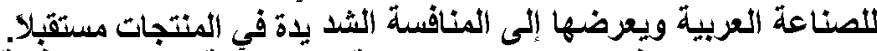

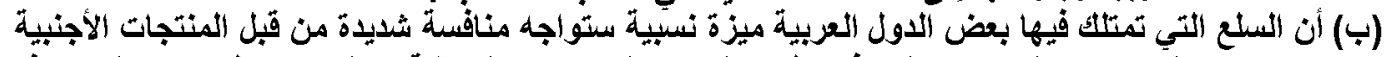

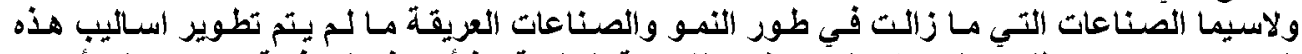

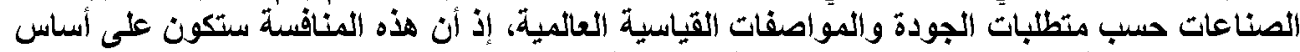

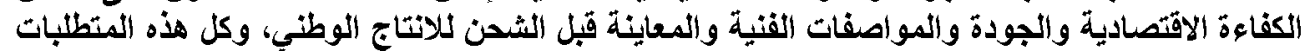

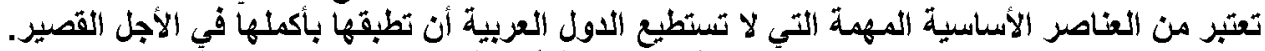

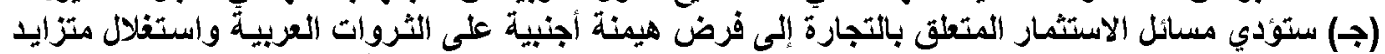

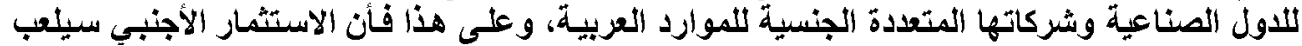

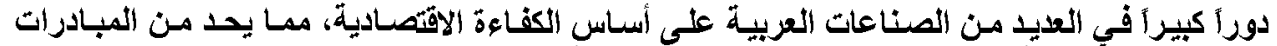

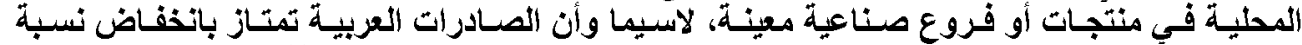

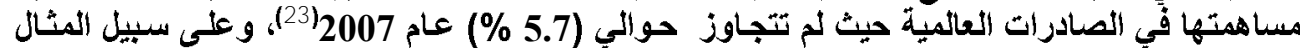

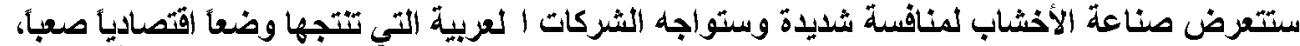

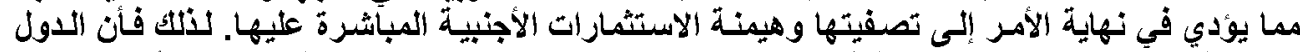

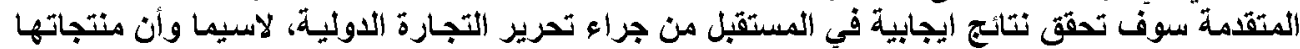

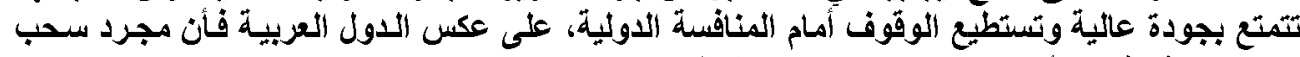

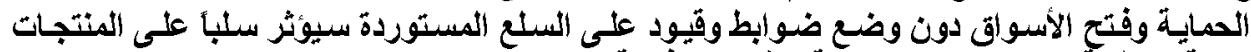

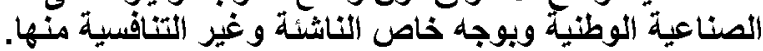




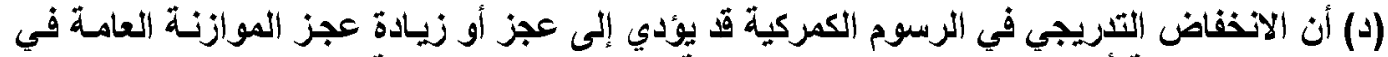

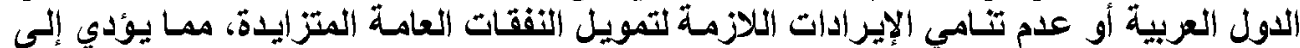

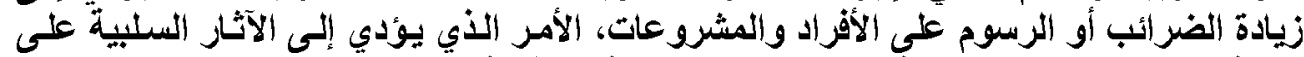

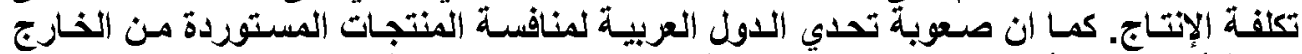

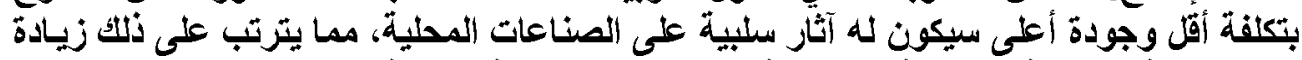

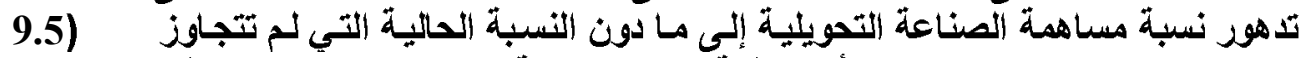

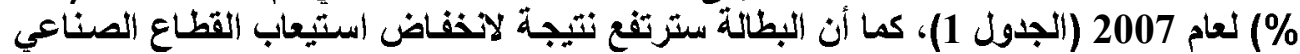
العربي للايدي العاملة، حيث لم يستوعب سوى (17 \%) من إجمالي العمالحة العربية كما أشرئا إلى ذلتك سلفاً.

(هـ ) أن تخفيض التعريفة على السلع الصناعية في الدول المتقامة سيؤدي إلى زيادة الأستيراد فيما

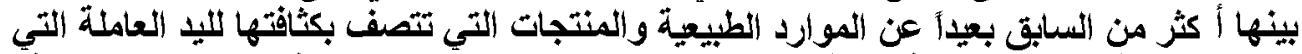

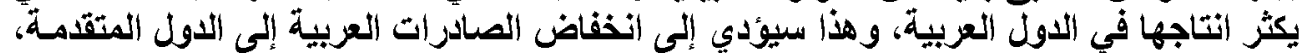

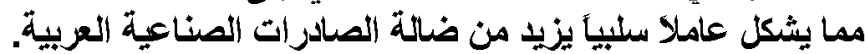

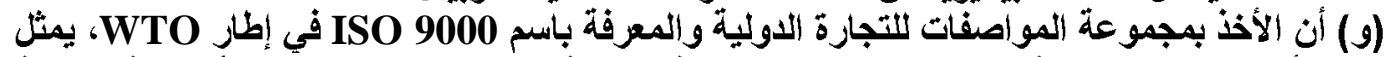

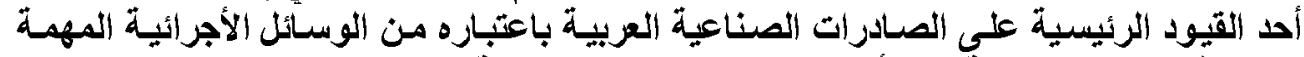

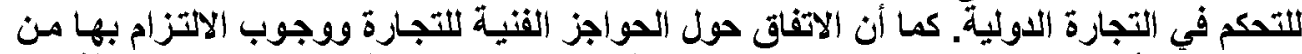

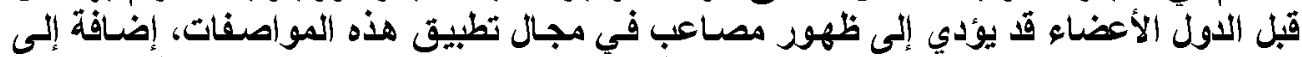

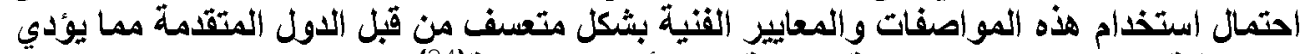

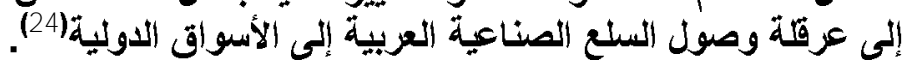
2- 20 الآثار الايجابية (الطويلة الأمد):

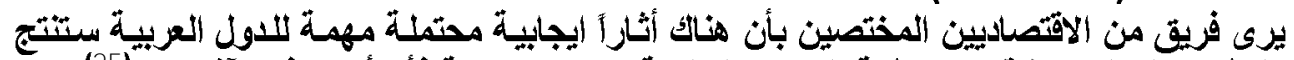

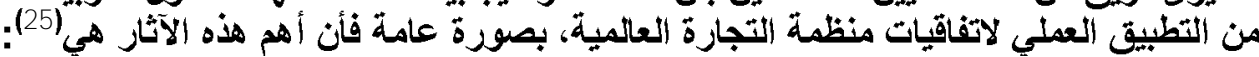

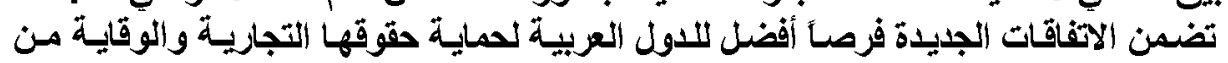

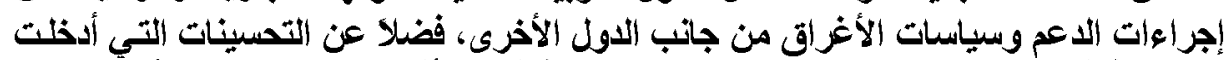

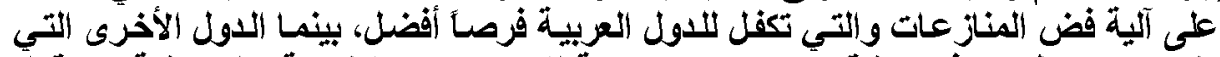

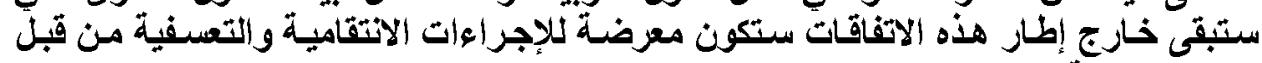

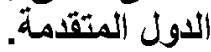
(ب) إن الأثفاقات الجيدة تتيح للاول العبية فرصاً أوسع للتصدير إلى الدول الأعضاء الأخرى

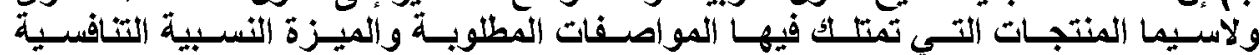

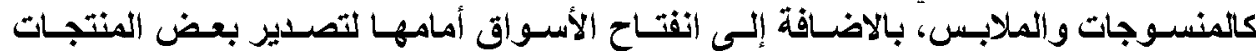

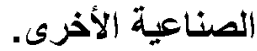

(ج) أن تخفيض القيود الكمركية وغير الكمركية سيؤدي إلى زيادة حجم التبادل التجاري الدولي

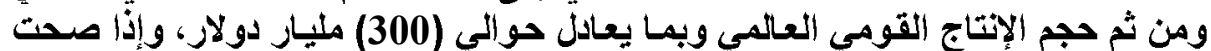

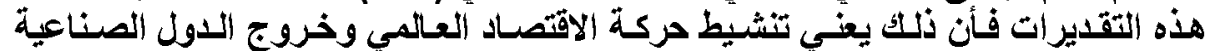

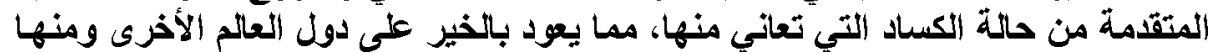

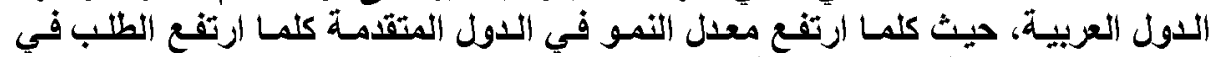
السواق الدول النامية ومنها العربية.

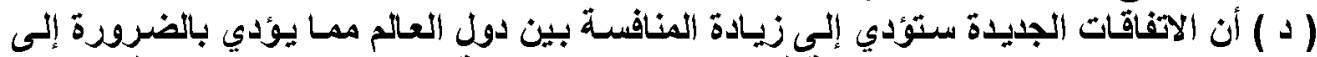

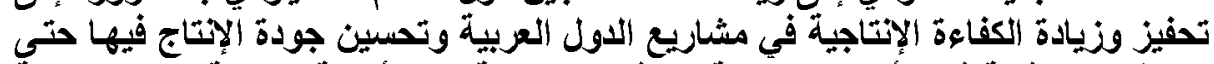

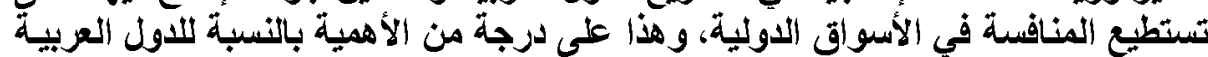
حتى تستطيع الاحتفاظ بسوقها المالي والحصول على نصيب من الأسواق الدولية. 


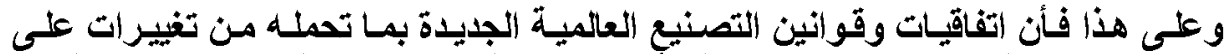

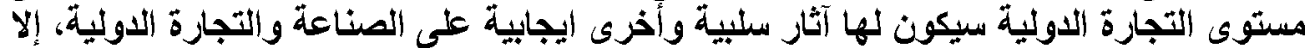

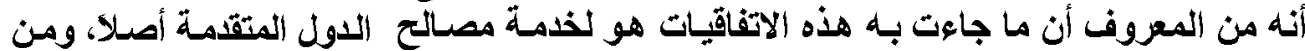

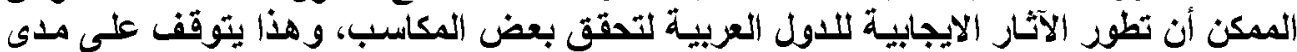

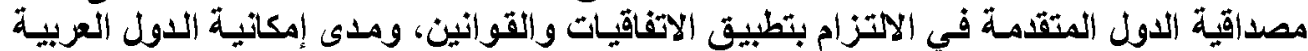

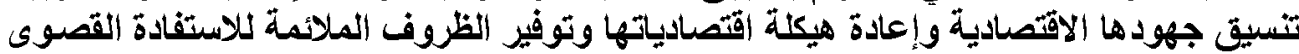

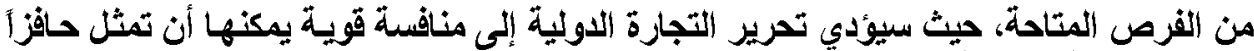

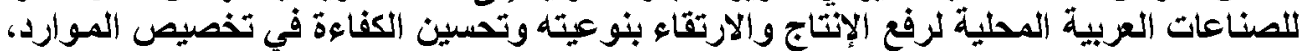

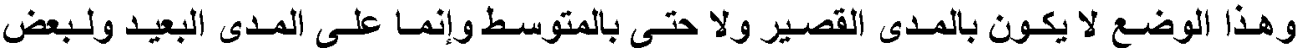

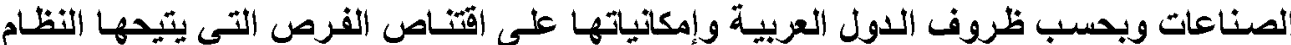

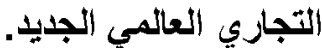

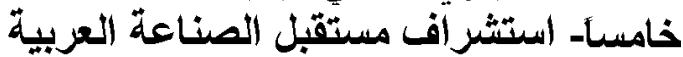

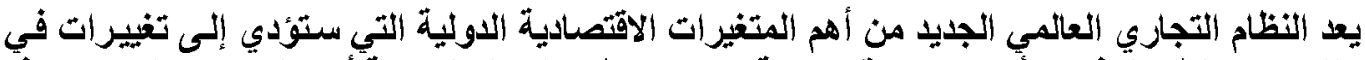

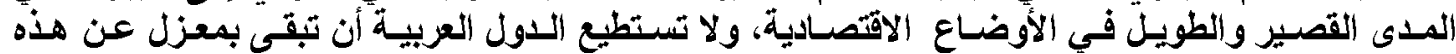

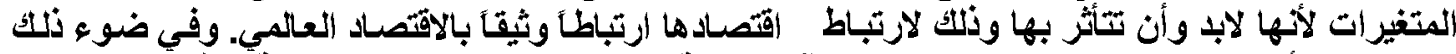

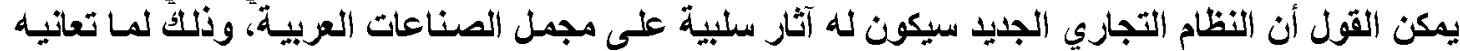

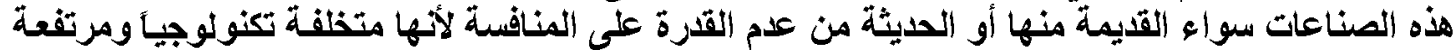

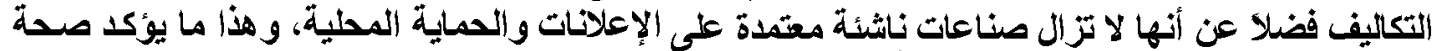

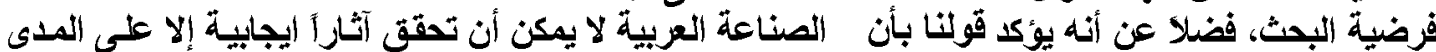

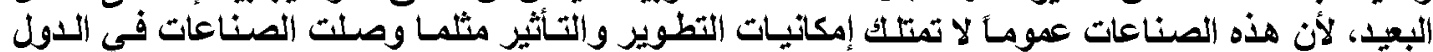

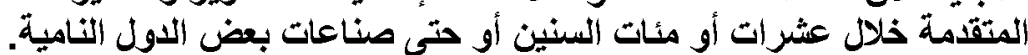

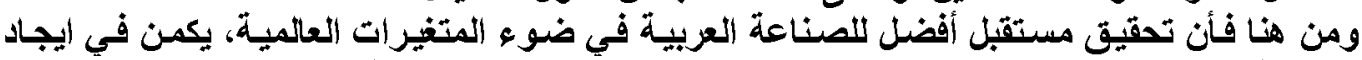

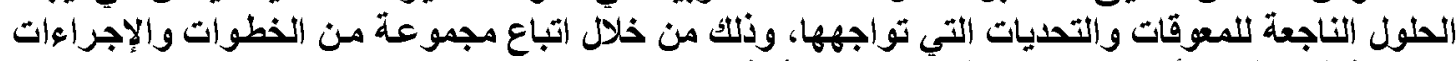

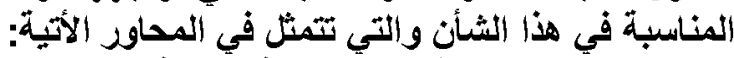

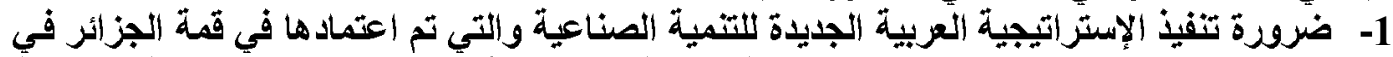

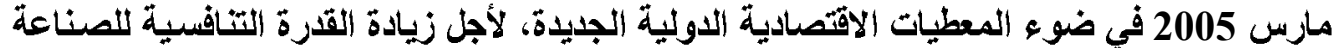

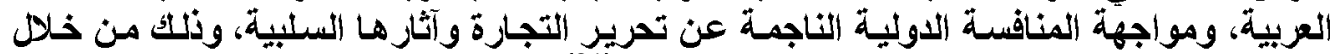

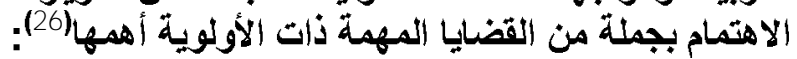

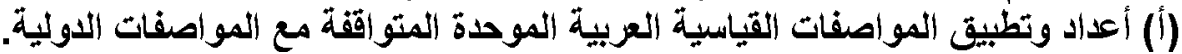

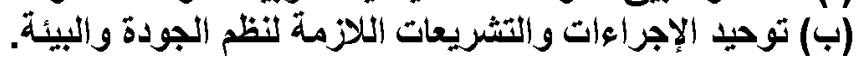

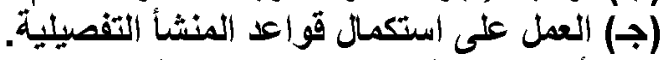

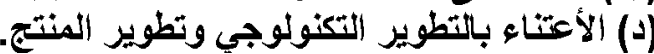

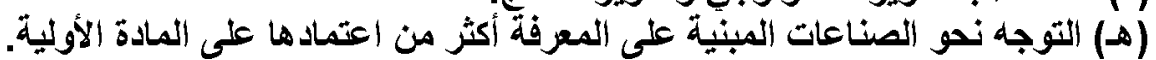

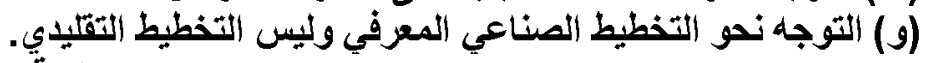
(ي) البحث عن الأسواق الجنيدة وخاصة الأسواق في الأول النامية.

2- يجب إعادة النظر في هيكلية الصناعة العربية بالاتجاه الأي يعز الاخول في الصناعناعات الأكثر حيويـة ذات

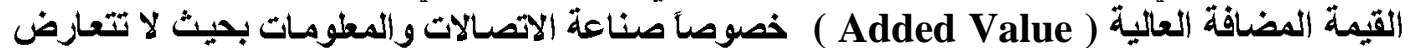

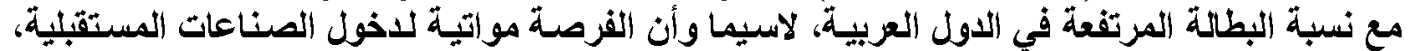

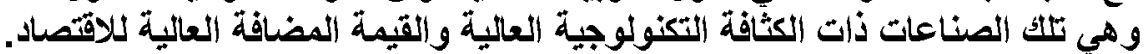


3- العمل على تنمية وتثويع الصادرات الصناعية العربية ورفع قدرتها التنافسية، وذلك على خلفيـة أن تقويـة

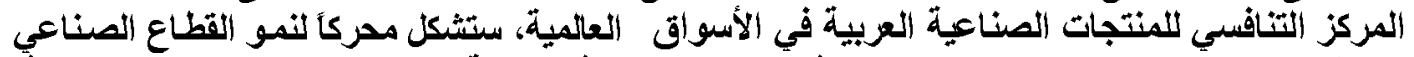

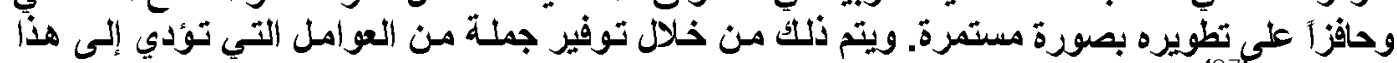

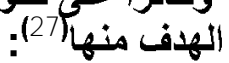
أ- رفع الإنتاجية الصناعية.

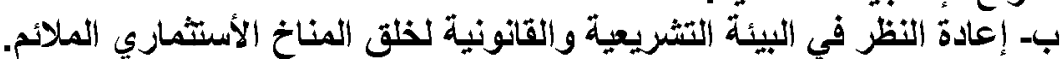

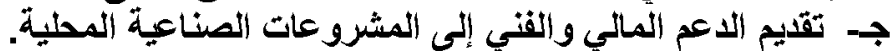

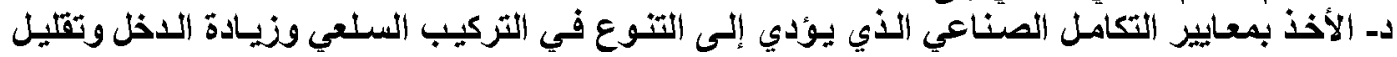

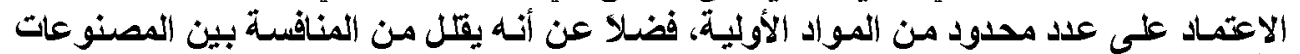

$$
\text { العربية. }
$$

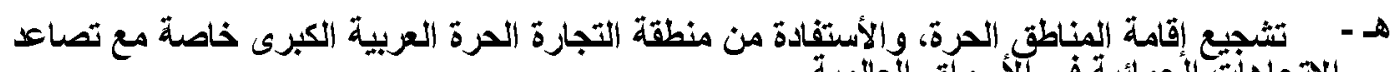

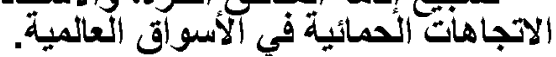

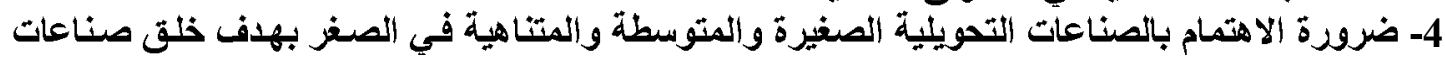

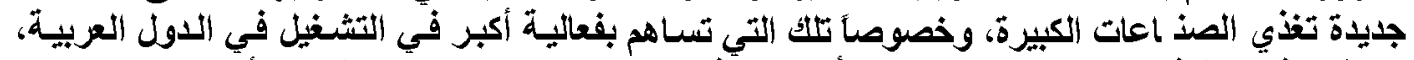

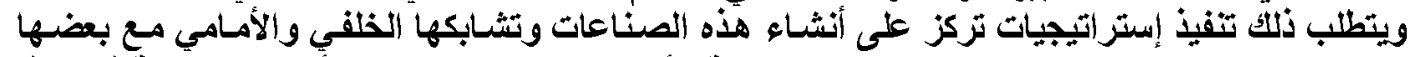

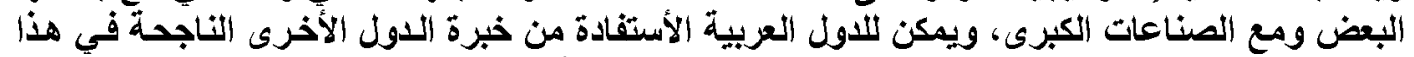

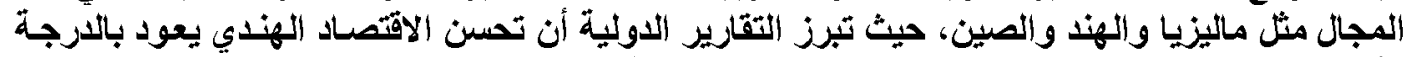

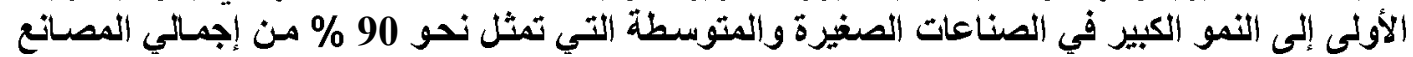

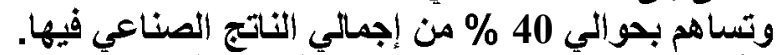

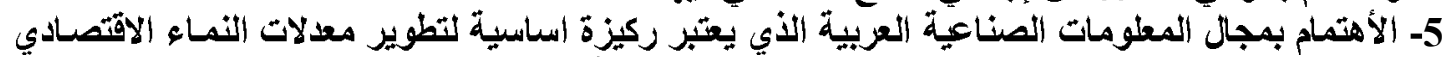

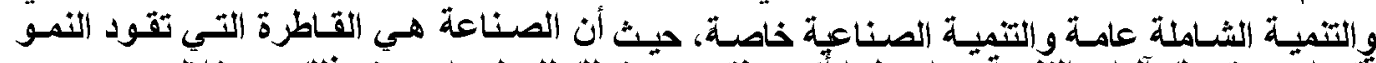

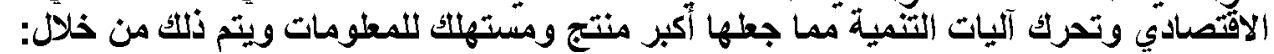

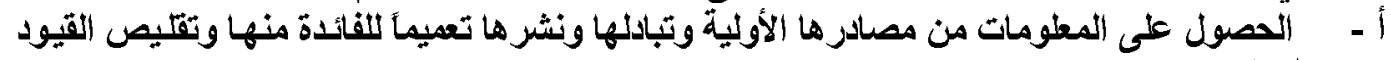
عليها. بـ استخدام النظام المفتوح الجديد ( Open Sources ) في تطوير قاعدتها المعلوماتية لتوفير أكبر

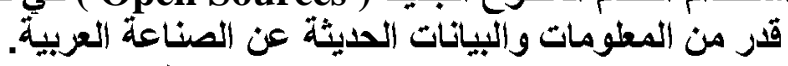

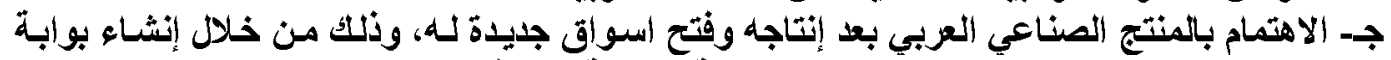

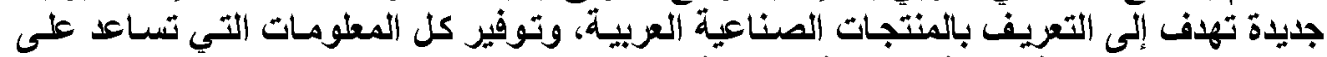

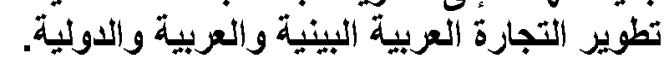

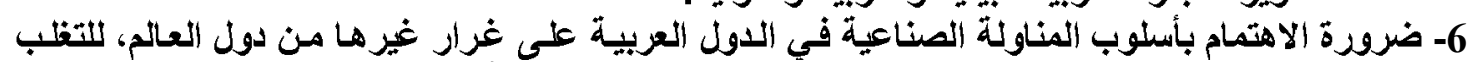

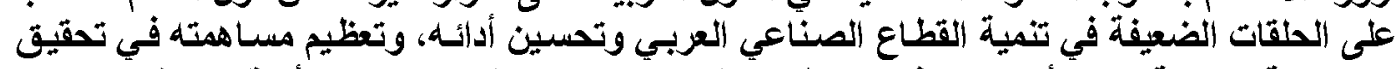

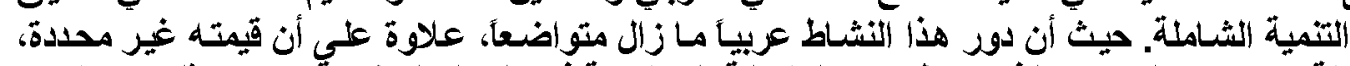

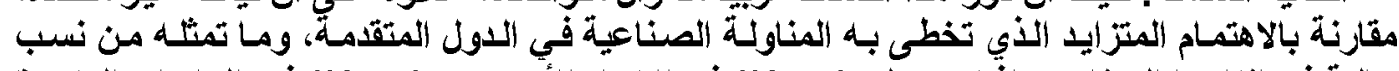

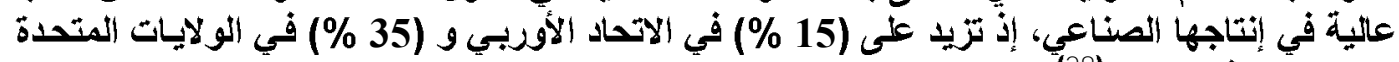

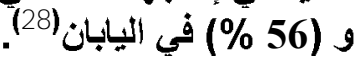

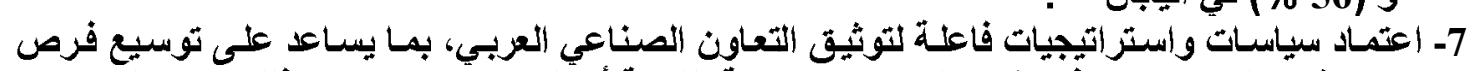

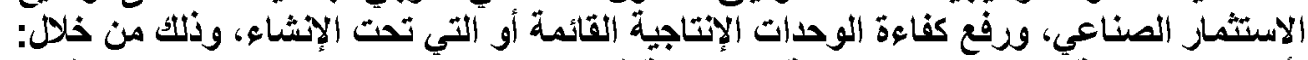

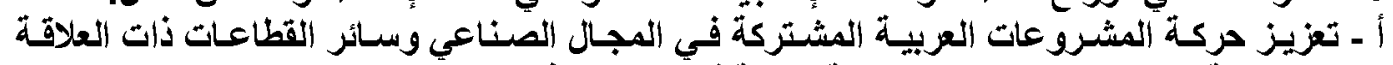

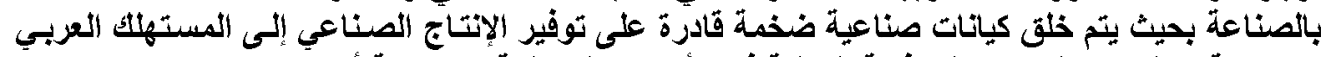

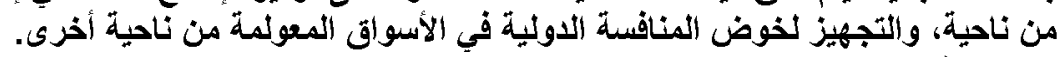

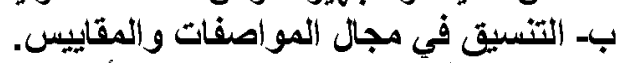

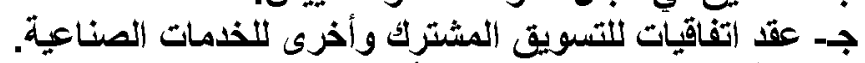

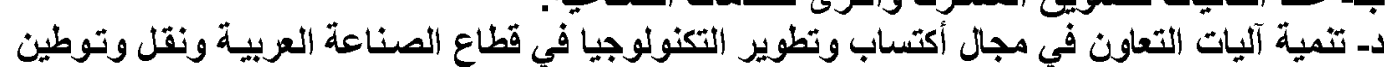
التكنولوجيا. 


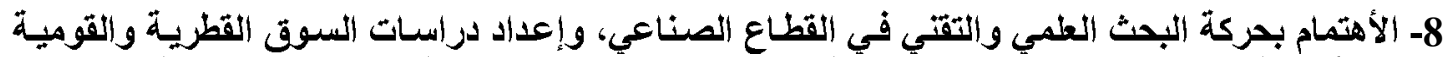

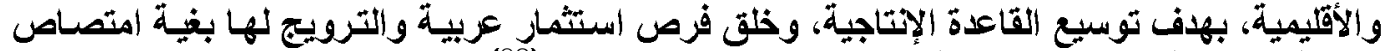

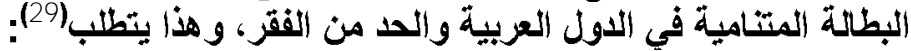

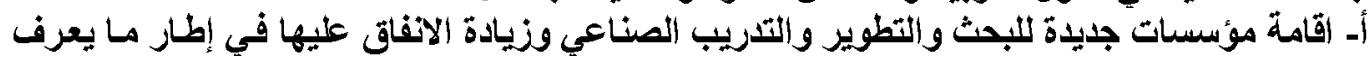

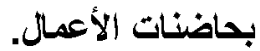

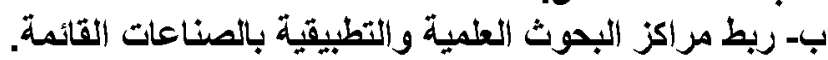

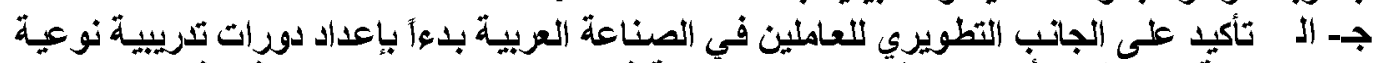

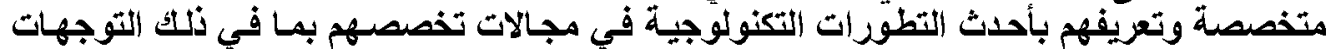

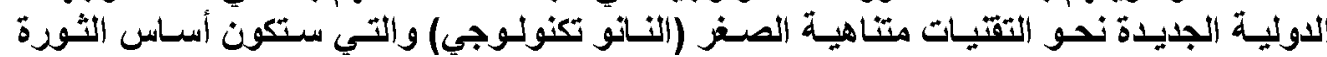

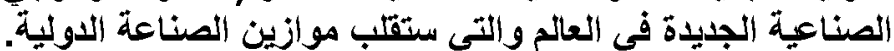

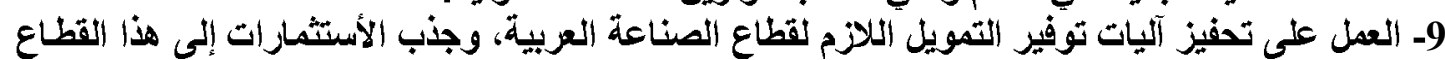

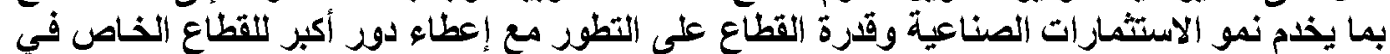

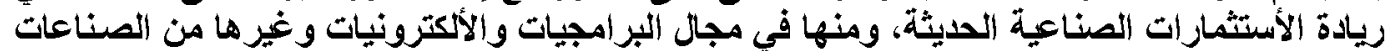
المتعلقة بالإنتاج المعرفي.

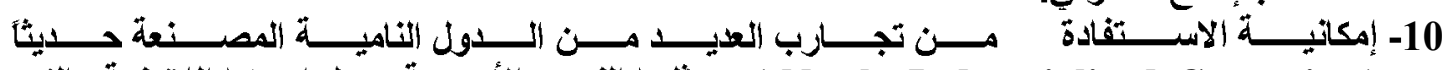

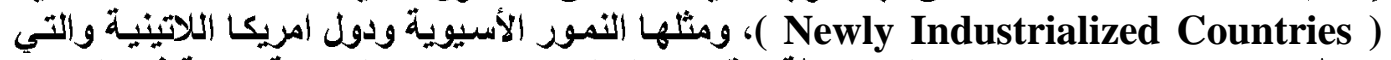

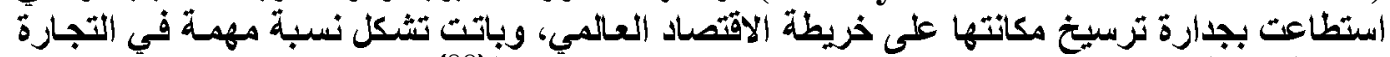

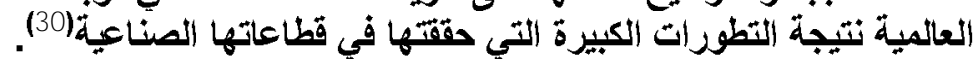




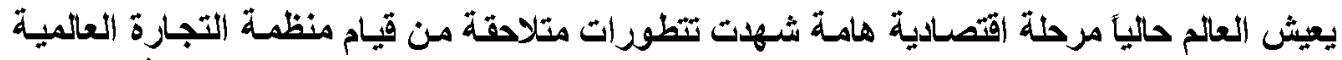

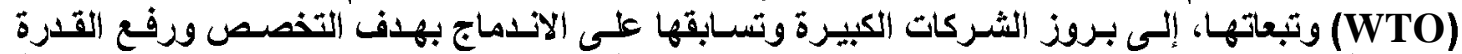

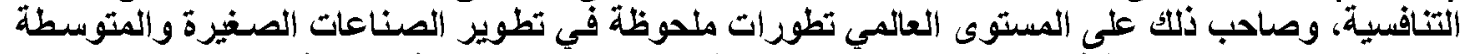

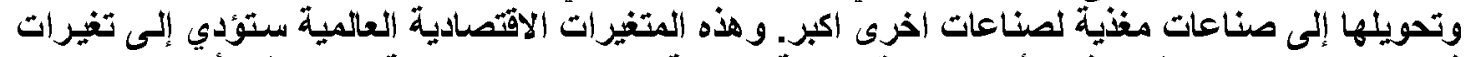

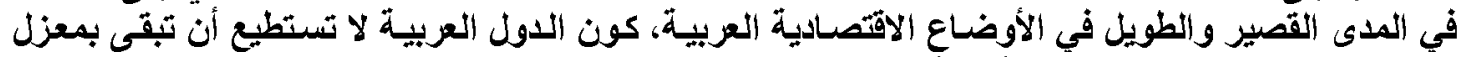

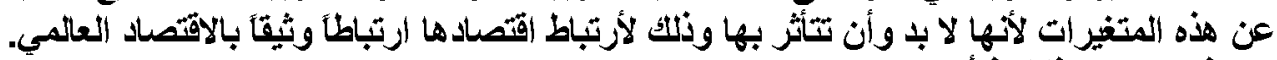

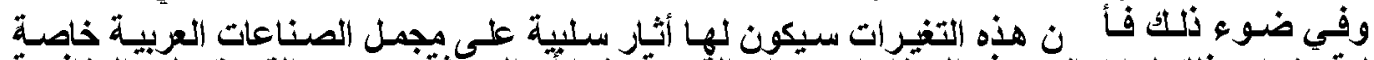

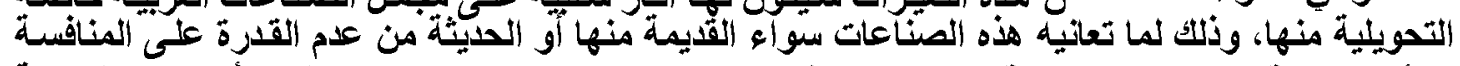

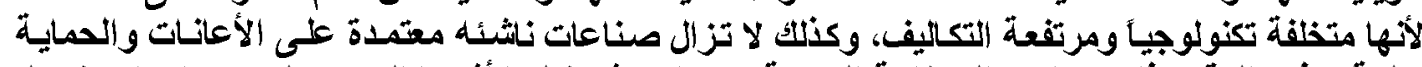

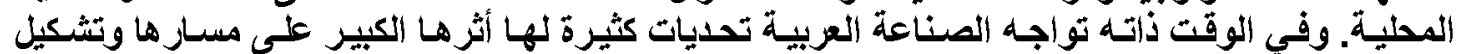

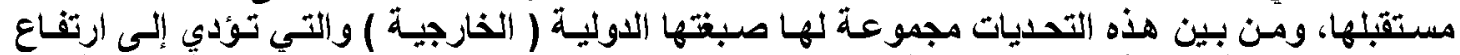

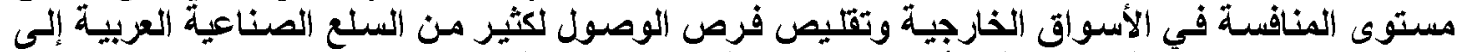

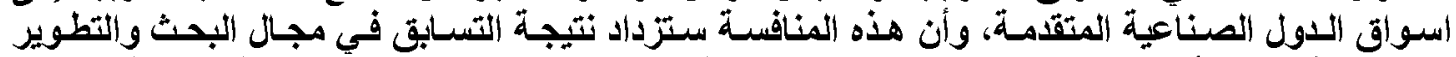

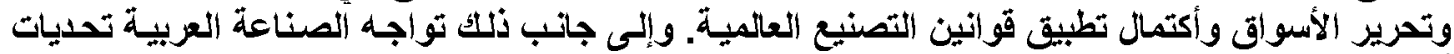

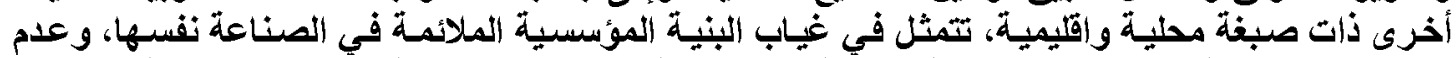

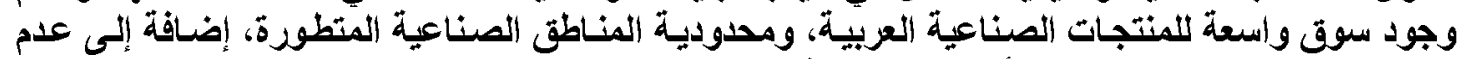

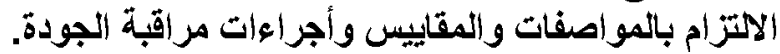

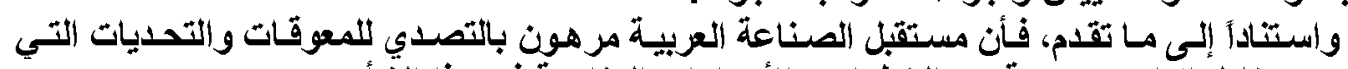

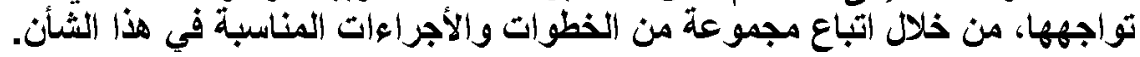




\section{المراجع حسب ورودها في البحث}

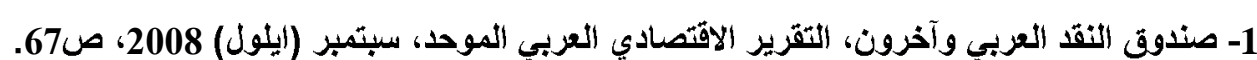

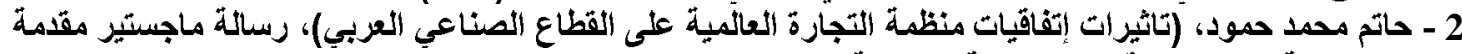

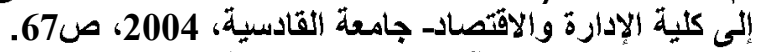

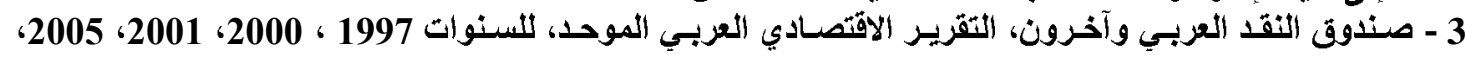

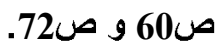

4 - د. حميد الجميلي، (الصناعات التحويلية العربيةـ الإثكاليات وتحديات المستقبل)، مجلة تنمية الرافدين، العدد 65،

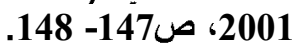

5 - صندوق النقا العربي وآخرون، التقريز الاقتصادي العربي الموحد، لسنة 2008، مصدر سابق، ص148.

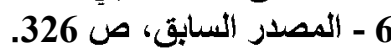

7 - عرفان الحسيني، (مستقبل الصناعة العربية في ظل عالم متفيز)، مجلة أخبار النفط والصناعة، العدد 418، السنة

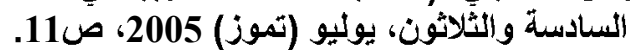

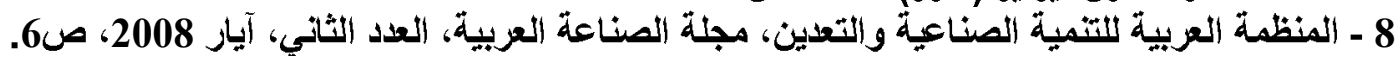

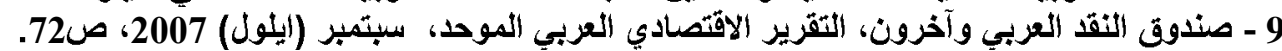

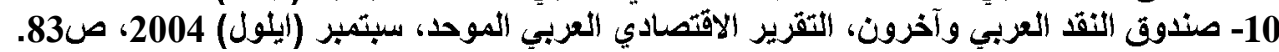

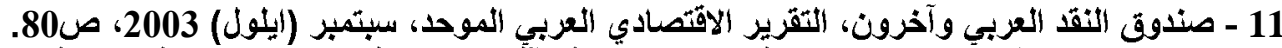

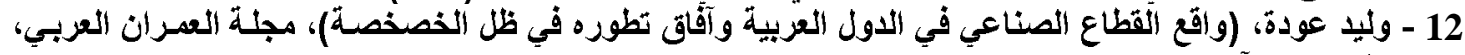

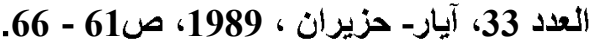

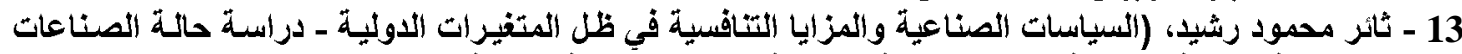

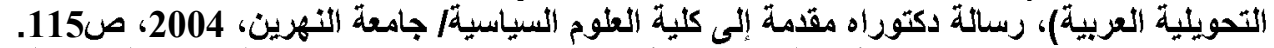

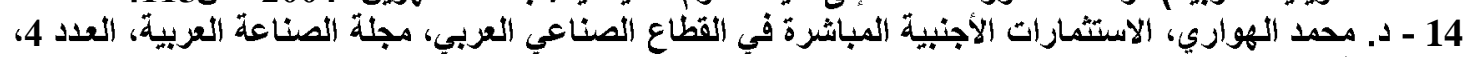

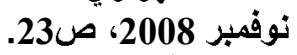

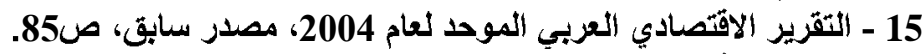

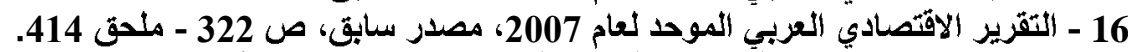

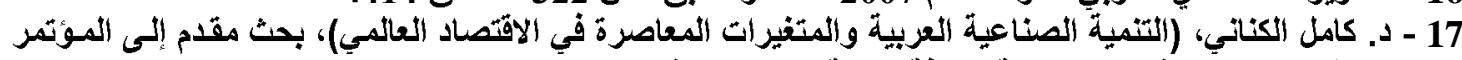

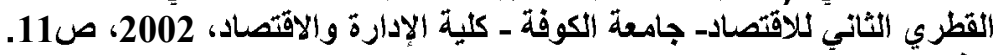

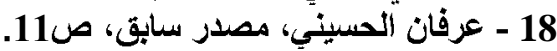

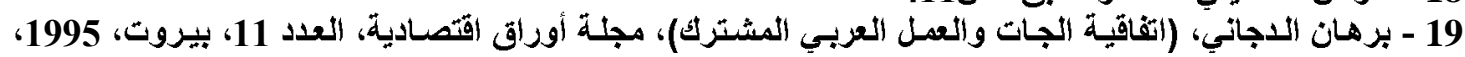

ص14.

20 - وليد عودة، (أراء حول منظمة التجارة العالمية من منظار عربي وعالمي)، مجلة أوراق اقتصادية، العدد 16،

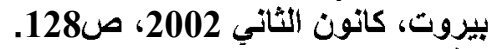

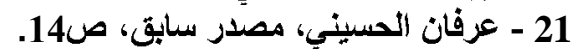

22 - د. ظافر حميد حسون، (منظمة التجارة العالمبة وتأثير هـا على البلدان النامية)، مجلة كلية التراث، العدد الأول،

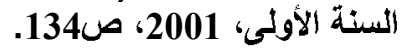

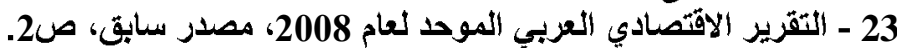

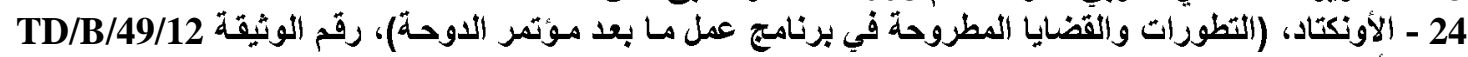

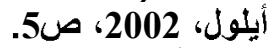

25 - محمد مأمون عبد القتاح، (انفاق التجارة في السلع الزراعية)، اللجنة الاقتصادية والاجتماعية لغزبي آسبا، الأمم

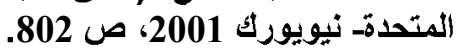

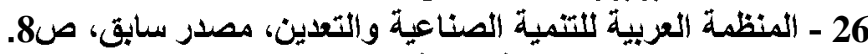

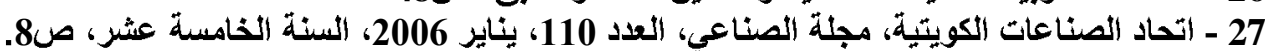

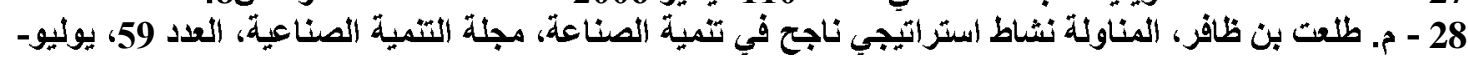

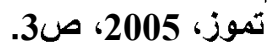

29 - د. أمير الرفاعى، الأمن الأسلىى والتمية الصناعية في الوطن العربي، مجلة الصناعة العربية، العدد 3، يونيو،

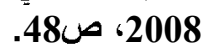

30 - عرفان الحسني، مصدر سابق، ص13. 